\title{
A High-Performance Liquid Chromatography-Tandem Mass Spectrometry Method for Quantitation of Nitrogen- Containing Intracellular Metabolites
}

\author{
Wenyun Lu, Elizabeth Kimball, and Joshua D. Rabinowitz \\ Lewis-Sigler Institute for Integrative Genomics and Department of Chemistry, Princeton University, \\ Princeton, New Jersey, USA
}

\begin{abstract}
A comprehensive method of quantifying intracellular metabolite concentrations would be a valuable addition to the arsenal of tools for holistic biochemical studies. Here, we describe a step toward the development of such method: a quantitative assay for 90 nitrogen-containing cellular metabolites. The assay involves reverse-phase high-performance liquid chromatography separation followed by electrospray ionization and detection of the resulting ions using triple-quadrupole mass spectrometry in selected reaction monitoring mode. For 79 of the 90 metabolites, the assay is linear with a limit of detection of $10 \mathrm{ng} / \mathrm{mL}$ or less. Using this method, 36 metabolites can be reliably detected in extracts of the bacterium Salmonella enterica, with the identity of each metabolite confirmed by the presence, on growing of the bacteria in ${ }^{13} \mathrm{C}$-glucose, of a peak corresponding to the isotope-labeled form of the compound. Quantitation in biological samples is performed by mixing unlabeled test cell extract with ${ }^{13} \mathrm{C}$-labeled standard extract, and determining the ${ }^{12} \mathrm{C} /{ }^{13} \mathrm{C}$-ratio for each metabolite. Using this approach, the metabolomes of growing (exponential phase) and carbon-starved (stationary phase) bacteria were compared, revealing 16 metabolites that are significantly down-regulated and five metabolites that are significantly up-regulated, in stationary phase. (J Am Soc Mass Spectrom 2006, 17, 37-50) () 2005 American Society for Mass Spectrometry
\end{abstract}

$\mathrm{T}$ The chemical reaction network of cellular metabolism, which produces complex biomolecules from simple nutrients, is highly conserved in living systems. The structure of the metabolic reaction network has been mapped in substantial detail using organic chemistry, biochemistry, and genetic approaches, with modern metabolic maps of certain wellstudied model organisms, such as enteric bacteria and bakers yeast, including some 500 different water-soluble compounds interconverting using appropriately 700 chemical reactions. Recent data from the sequencing of the complete genomes of these organisms suggest that the majority of all major, nonlipid metabolic transformations required for their survival and growth are captured in current maps [1-7]. Thus, for certain model organisms, there is now an opportunity to shift from metabolite structure identification and qualitative description of reaction pathways to quantitative analysis of the rates and regulation of cellular metabolic reactions.

A major barrier to quantitative understanding of the cellular metabolic network has been the lack of appro-

Published online December 15, 2005

Address reprint requests to Joshua D. Rabinowitz, M.D., Ph.D., Lewis-Sigler Institute for Integrative Genomics, 241 Carl Icahn Laboratory, Princeton University, Princeton, NJ 08544, USA. E-mail: joshr@genomics.princeton.edu priate tools for metabolite concentration measurement. Although assays, often enzyme-based, for determining the concentrations of certain metabolites on a one-byone basis have been available for some time [8-10], methods for simultaneous quantitation of numerous metabolites are only now being developed for the first time. A major challenge in the development of these assays is the low abundance of most intracellular metabolites. In total, metabolites comprise only approximately $3 \%$ of cell dry weight of enteric bacteria [11]. Of this amount, a large preponderance is in the form of a few prevalent species, for example, in enteric bacteria, glutamate [12-15], with most metabolites present in only very small quantities. Thus, many metabolites are proverbial "needles" in the "haystack" of more prevalent metabolites and other biomolecules.

Previous efforts to measure multiple metabolites in parallel have applied a variety of approaches, including thin-layer chromatography (TLC) [13, 14], high-performance liquid chromatography (HPLC) with detection based on absorption or emission of light [12, 15], nuclear magnetic resonance spectroscopy [16, 17], and chromatography coupled to mass spectrometry [18-23]. Approaches not using mass spectrometry detection, although able to produce characteristic signal patterns for metabolite mixtures, suffer from both low sensitivity (unless radioactive labeling is used) and low specificity 
(difficulty relating observed peaks to particular molecular entities). For example, a recent study of intracellular metabolites by two-dimensional TLC, although impressively resolving up to 99 spots, was able to quantify only 23 of these spots and to associate only 13 of these with particular chemical species [14]. Mass spectrometry, in contrast, has the potential to detect metabolites with high sensitivity in the absence of radioactive labeling and to distinguish even closely related species based on molecular weight.

To date, the bulk of metabolite quantitation by mass spectrometry has focused on drug metabolites or serum biomarkers [19, 24-26], not intracellular metabolites. For biomarker measurement, a common approach is to couple HPLC to a mass spectrometer with high mass accuracy, such as a time-of-flight instrument. This approach has enabled approximate quantitation of approximately 1500 molecular ions from human serum, a remarkable achievement [19]. Most of these molecular ions were not, however, associated specifically with known metabolites, and the ability of this technique to detect intracellular metabolites was not reported. For quantitation of known metabolites (usually of drugs) from complex matrices such as serum, a sensitive approach is to couple HPLC to a triple-quadrupole mass spectrometer operating in selected reaction monitoring (SRM) mode. Accurate quantitation is ensured by incorporation of isotope-labeled internal standard of the metabolite of interest in the analysis mixture. This approach seems well suited to measurement of intracellular metabolites, where the molecular entities of interest are known and sensitivity is of paramount importance. Isotope-labeled internal standard (for a test culture grown in nutrients of the experimenter's choosing) can be generated by growing a control culture of cells in isotope-labeled nutrient (e.g., ${ }^{13} \mathrm{C}$-glucose) [21]. Alternatively, to enable absolute quantitation of metabolites, an extract of test cells grown in isotope-labeled glucose can be spiked with commercially available, unlabeled, purified metabolites as the internal control. Heijnen and colleagues recently have applied this technique to measure 11 different intracellular metabolites involved in central carbon metabolism [23]. The ability to scale up this technique, however, to measure a much larger number of metabolites, has been unclear, given the historical tendency to apply SRM scanning to study only a few analytes at once. To investigate this possibility, we attempted to develop a method that enables simultaneous measurement of numerous nitrogen-containing metabolites, because nitrogen-containing compounds constitute a majority of the known metabolites of enteric bacteria included in current metabolic maps [4] and generally ionize well by electrospray in positive ion mode. Here, we report the development of a method that enables simultaneous measurement of 90 such compounds, with sufficient sensitivity to quantify reliably 36 of these metabolites from bacterial cells.

\section{Experimental}

\section{Chemicals and Reagents}

HPLC-grade solvents (water, methanol, and acetonitrile; OmniSolv, EMD Chemical) were obtained through VWR International (West Chester, PA). Formic acid (88\%) was purchased from Fisher Scientific (Pittsburgh, PA). All the 90 purified metabolite standards (see Table 1 ), as well as reserpine and all media components (see section Bacterial Strain and Culture Conditions), were obtained through Sigma-Aldrich (St. Louis, MO) and are $98 \%$ or more pure according to the manufacturer. ${ }^{13} \mathrm{C}$-D-glucose $(99 \%)$ was obtained from Cambridge Isotope Laboratories (Andover, MA).

For each purified metabolite, stock solution $(\geq 100$ $\mu \mathrm{g} / \mathrm{mL}$ ) was prepared in 50:50 methanol/water with $0.1 \%$ formic acid and stored at $-80{ }^{\circ} \mathrm{C}$. Fresh samples were prepared every 3 months or more often as needed. For liquid chromatography-tandem mass spectrometry (LC-MS/MS) studies, working solutions at $1 \mu \mathrm{g} / \mathrm{mL}$, as well as mixed compound solutions at various concentrations, were prepared as needed.

\section{Instrumentation}

Mass spectrometric analyses were performed on a Finnigan TSQ Quantum Ultra triple-quadrupole mass spectrometer (Thermo Electron Corporation, San Jose, $\mathrm{CA})$, equipped with electrospray ionization (ESI) source operated in positive-ion mode. The mass spectrometer syringe pump was used to infuse purified compounds for initial studies of MS/MS fragmentation and, subsequently, LC-MS/MS was performed using a LC-10A HPLC system (Shimadzu, Columbia, MD) coupled to the mass spectrometer. The mass spectrometer was controlled by the Quantum Tune Master software (Thermo Electron Corporation, version 1.2). Nitrogen was used as sheath gas and auxiliary gas and argon was used as the collision gas. The mass spectrometer was initially calibrated and ionization was optimized using the polytyrosine-1,3,6 standards (Thermo Electron Corporation), as well as metabolite standards, with the optimized ionization conditions for the selected LC solvent and flow rate (water/methanol at $100 \mu \mathrm{L} / \mathrm{min}$ ) being spray voltage $3200 \mathrm{~V}$, sheath gas $30 \mathrm{psi}$, auxiliary gas $10 \mathrm{psi}$, and capillary temperature $325^{\circ} \mathrm{C}$. In the SRM mode for MS/MS analysis, collision gas pressure was 1.5 mtorr with a scan time for each SRM transition of $0.1 \mathrm{~s}$ and a scan width of $1 \mathrm{~m} / \mathrm{z}$. The instrument control, data acquisition, and data analysis were performed by the Xcalibar software (Thermo Electron Corporation, version 1.4 SR1), which also controlled the chromatography system. The LC parameters were as follows: autosampler temperature, $4{ }^{\circ} \mathrm{C}$; injection volume, $10 \mu \mathrm{L}$; column temperature, $15^{\circ} \mathrm{C}$; and flow rate, $100 \mu \mathrm{L} / \mathrm{min}$. 
Table 1. LC-MS/MS parameters and results for 90 purified nitrogen-containing metabolites

\begin{tabular}{|c|c|c|c|c|c|c|c|c|}
\hline Compound $^{a}$ & $\begin{array}{l}\text { Neutral } \\
\text { formula }\end{array}$ & $\begin{array}{c}\text { Parent } \\
\text { mass }\end{array}$ & $\begin{array}{c}\text { Collision } \\
\text { energy } \\
(\mathrm{eV})\end{array}$ & $\begin{array}{l}\text { Preferred } \\
\text { product }^{b}\end{array}$ & $\begin{array}{l}\text { Mass of } \\
\text { preferred } \\
\text { product }\end{array}$ & $\begin{array}{l}\text { Masses of } \\
\text { other major } \\
\text { products }^{\mathrm{c}}\end{array}$ & $\begin{array}{c}\mathrm{RT}^{\mathrm{d}} \\
\text { (minutes) }\end{array}$ & $\begin{array}{c}\mathrm{LOD}^{\mathrm{e}} \\
(\mathrm{ng} / \mathrm{mL})\end{array}$ \\
\hline Urea & $\mathrm{CH}_{4} \mathrm{~N}_{2} \mathrm{O}$ & 61 & 20 & $\mathrm{CH}_{2} \mathrm{NO}^{+}$ & 44 & $\mathrm{~N} / \mathrm{A}$ & 7.7 & 100 \\
\hline Glycine & $\mathrm{C}_{2} \mathrm{H}_{5} \mathrm{NO}_{2}$ & 76 & 16 & $\mathrm{CH}_{4} \mathrm{~N}^{+}$ & 30 & 43,44 & 6.5 & 10 \\
\hline Putrescine & $\mathrm{C}_{4} \mathrm{H}_{12} \mathrm{~N}_{2}$ & 89 & 11 & $\mathrm{C}_{4} \mathrm{H}_{10} \mathrm{~N}^{+}$ & 72 & 30 & 5.0 & 0.5 \\
\hline Alanine & $\mathrm{C}_{3} \mathrm{H}_{7} \mathrm{NO}_{2}$ & 90 & 11 & $\mathrm{C}_{2} \mathrm{H}_{6} \mathrm{~N}^{+}$ & 44 & N/A & 6.7 & 10 \\
\hline Betaine aldehyde & $\mathrm{C}_{5} \mathrm{H}_{11} \mathrm{NO}$ & 102 & 17 & $\mathrm{C}_{3} \mathrm{H}_{9} \mathrm{~N}^{+}$ & 59 & 42,58 & $7.0,8.0$ & 10 \\
\hline Choline & $\mathrm{C}_{5} \mathrm{H}_{13} \mathrm{NO}$ & 104 & 19 & $\mathrm{C}_{3} \mathrm{H}_{10} \mathrm{~N}^{+}$ & 60 & $42,45,58$ & 8.0 & 1 \\
\hline Serine & $\mathrm{C}_{3} \mathrm{H}_{7} \mathrm{NO}_{3}$ & 106 & 13 & $\mathrm{C}_{2} \mathrm{H}_{6} \mathrm{NO}^{+}$ & 60 & 42,70 & 6.6 & 5 \\
\hline Cytosine & $\mathrm{C}_{4} \mathrm{H}_{5} \mathrm{~N}_{3} \mathrm{O}$ & 112 & 17 & $\mathrm{C}_{4} \mathrm{H}_{3} \mathrm{~N}_{2} \mathrm{O}^{+}$ & 95 & 52,69 & 6.4 & 10 \\
\hline Uracil & $\mathrm{C}_{4} \mathrm{H}_{4} \mathrm{~N}_{2} \mathrm{O}_{2}$ & 113 & 23 & $\mathrm{C}_{3} \mathrm{H}_{4} \mathrm{NO}^{+}$ & 70 & $40,43,96$ & 12.0 & 50 \\
\hline Proline & $\mathrm{C}_{5} \mathrm{H}_{9} \mathrm{NO}_{2}$ & 116 & 11 & $\mathrm{C}_{4} \mathrm{H}_{8} \mathrm{~N}^{+}$ & 70 & 68 & 7.8 & 5 \\
\hline Valine & $\mathrm{C}_{5} \mathrm{H}_{11} \mathrm{NO}_{2}$ & 118 & 11 & $\mathrm{C}_{4} \mathrm{H}_{7}^{+}$ & 55 & 72 & 7.8 & 5 \\
\hline Threonine & $\mathrm{C}_{4} \mathrm{H}_{9} \mathrm{NO}_{3}$ & 120 & 30 & $\mathrm{C}_{3} \mathrm{H}_{5} \mathrm{O}^{+}$ & 57 & $56,74,102$ & 6.8 & 10 \\
\hline Homoserine & $\mathrm{C}_{4} \mathrm{H}_{9} \mathrm{NO}_{3}$ & 120 & 30 & $\mathrm{C}_{2} \mathrm{H}_{6} \mathrm{~N}^{+}$ & 44 & $56,74,102$ & 6.8 & 10 \\
\hline Cysteine & $\mathrm{C}_{3} \mathrm{H}_{7} \mathrm{NO}_{2} \mathrm{~S}$ & 122 & 27 & $\mathrm{C}_{2} \mathrm{H}_{3} \mathrm{~S}^{+}$ & 59 & 76,87 & 7.2 & 5 \\
\hline Nicotinamide & $\mathrm{C}_{6} \mathrm{H}_{6} \mathrm{~N}_{2} \mathrm{O}$ & 123 & 20 & $\mathrm{C}_{5} \mathrm{H}_{6} \mathrm{~N}^{+}$ & 80 & 53,78 & 12.5 & 10 \\
\hline Nicotinic acid & $\mathrm{C}_{6} \mathrm{H}_{5} \mathrm{NO}_{2}$ & 124 & 20 & $\mathrm{C}_{5} \mathrm{H}_{6} \mathrm{~N}^{+}$ & 80 & 53,78 & 11.6 & 10 \\
\hline Taurine & $\mathrm{C}_{2} \mathrm{H}_{7} \mathrm{NO}_{3} \mathrm{~S}$ & 126 & 10 & $\mathrm{C}_{2} \mathrm{H}_{6} \mathrm{NO}_{2} \mathrm{~S}^{+}$ & 108 & 44 & 6.9 & 50 \\
\hline Thymine & $\mathrm{C}_{5} \mathrm{H}_{6} \mathrm{~N}_{2} \mathrm{O}_{2}$ & 127 & 17 & $\mathrm{C}_{5} \mathrm{H}_{4} \mathrm{NO}_{2}^{+}$ & 110 & $54,56,84$ & 22.7 & 10 \\
\hline Agmatine & $\mathrm{C}_{5} \mathrm{H}_{14} \mathrm{~N}_{4}$ & 131 & 16 & $\mathrm{C}_{4} \mathrm{H}_{10} \mathrm{~N}^{+}$ & 72 & $60,97,114$ & 5.3 & 1 \\
\hline Isoleucine/leucine & $\mathrm{C}_{6} \mathrm{H}_{13} \mathrm{NO}_{2}$ & 132 & 11 & $\mathrm{C}_{5} \mathrm{H}_{12} \mathrm{~N}^{+}$ & 86 & 44,69 & $8.6,11.0$ & 10 \\
\hline Ornithine & $\mathrm{C}_{5} \mathrm{H}_{12} \mathrm{~N}_{2} \mathrm{O}_{2}$ & 133 & 12 & $\mathrm{C}_{4} \mathrm{H}_{8} \mathrm{~N}^{+}$ & 70 & 116 & 5.6 & 5 \\
\hline Asparagine & $\mathrm{C}_{4} \mathrm{H}_{8} \mathrm{~N}_{2} \mathrm{O}_{3}$ & 133 & 17 & $\mathrm{C}_{2} \mathrm{H}_{4} \mathrm{NO}_{2}{ }^{+}$ & 74 & 70,87 & 6.9 & 5 \\
\hline Aspartic acid & $\mathrm{C}_{4} \mathrm{H}_{7} \mathrm{NO}_{4}$ & 134 & 15 & $\mathrm{C}_{2} \mathrm{H}_{4} \mathrm{NO}_{2}{ }^{+}$ & 74 & 70,88 & 6.8 & 5 \\
\hline Adenine & $\mathrm{C}_{5} \mathrm{H}_{5} \mathrm{~N}_{5}$ & 136 & 24 & $\mathrm{C}_{5} \mathrm{H}_{3} \mathrm{~N}_{4}^{+}$ & 119 & $65,92,94$ & 7.8 & 0.5 \\
\hline Hypoxanthine & $\mathrm{C}_{5} \mathrm{H}_{4} \mathrm{~N}_{4} \mathrm{O}$ & 137 & 19 & $\mathrm{C}_{4} \mathrm{H}_{4} \mathrm{~N}_{3} \mathrm{O}^{+}$ & 110 & 94,119 & 17.0 & 10 \\
\hline$p$-Aminobenzoic acid & $\mathrm{C}_{7} \mathrm{H}_{7} \mathrm{NO}_{2}$ & 138 & 24 & $\mathrm{C}_{6} \mathrm{H}_{5}^{+}$ & 77 & $65,92,120$ & 28.8 & 10 \\
\hline Anthranilic acid & $\mathrm{C}_{7} \mathrm{H}_{7} \mathrm{NO}_{2}$ & 138 & 20 & $\mathrm{C}_{6} \mathrm{H}_{6} \mathrm{~N}^{+}$ & 92 & 65,120 & 35.0 & 0.5 \\
\hline Histidinol & $\mathrm{C}_{6} \mathrm{H}_{11} \mathrm{~N}_{3} \mathrm{O}$ & 142 & 18 & $\mathrm{C}_{5} \mathrm{H}_{7} \mathrm{~N}_{2}^{+}$ & 95 & 81,124 & 5.1 & 5 \\
\hline Spermidine & $\mathrm{C}_{7} \mathrm{H}_{19} \mathrm{~N}_{3}$ & 146 & 13 & $\mathrm{C}_{7} \mathrm{H}_{14} \mathrm{~N}^{+}$ & 112 & $58,72,84$ & 4.9 & 50 \\
\hline Lysine & $\mathrm{C}_{6} \mathrm{H}_{14} \mathrm{~N}_{2} \mathrm{O}_{2}$ & 147 & 15 & $\mathrm{C}_{5} \mathrm{H}_{10} \mathrm{~N}^{+}$ & 84 & 130 & 5.5 & 1 \\
\hline Glutamine & $\mathrm{C}_{5} \mathrm{H}_{10} \mathrm{~N}_{2} \mathrm{O}_{3}$ & 147 & 15 & $\mathrm{C}_{4} \mathrm{H}_{6} \mathrm{NO}^{+}$ & 84 & $41,56,130$ & 6.8 & 0.1 \\
\hline Glutamate & $\mathrm{C}_{5} \mathrm{H}_{9} \mathrm{NO}_{4}$ & 148 & 15 & $\mathrm{C}_{4} \mathrm{H}_{6} \mathrm{NO}^{+}$ & 84 & $41,56,102$ & 6.8 & 1 \\
\hline O-acetyl-L-serine & $\mathrm{C}_{5} \mathrm{H}_{9} \mathrm{NO}_{4}$ & 148 & 12 & $\mathrm{C}_{3} \mathrm{H}_{8} \mathrm{NO}_{3}{ }^{+}$ & 106 & $42,60,88$ & 7.4 & 5 \\
\hline Methionine & $\mathrm{C}_{5} \mathrm{H}_{11} \mathrm{NO}_{2} \mathrm{~S}$ & 150 & 10 & $\mathrm{C}_{5} \mathrm{H}_{9} \mathrm{O}_{2} \mathrm{~S}^{+}$ & 133 & $56,61,104$ & 7.9 & 10 \\
\hline Guanine & $\mathrm{C}_{5} \mathrm{H}_{5} \mathrm{~N}_{5} \mathrm{O}$ & 152 & 16 & $\mathrm{C}_{5} \mathrm{H}_{3} \mathrm{~N}_{4} \mathrm{O}^{+}$ & 135 & 110 & 7.8 & 10 \\
\hline Xanthine & $\mathrm{C}_{5} \mathrm{H}_{4} \mathrm{~N}_{4} \mathrm{O}_{2}$ & 153 & 16 & $\mathrm{C}_{4} \mathrm{H}_{4} \mathrm{~N}_{3} \mathrm{O}^{+}$ & 110 & 81,136 & 22.0 & 10 \\
\hline Histidine & $\mathrm{C}_{6} \mathrm{H}_{9} \mathrm{~N}_{3} \mathrm{O}_{2}$ & 156 & 12 & $\mathrm{C}_{5} \mathrm{H}_{8} \mathrm{~N}_{3}^{+}$ & 110 & 83,93 & 5.7 & 5 \\
\hline Orotic acid & $\mathrm{C}_{5} \mathrm{H}_{4} \mathrm{~N}_{2} \mathrm{O}_{4}$ & 157 & 25 & $\mathrm{C}_{3} \mathrm{H}_{2} \mathrm{NO}^{+}$ & 68 & $70,79,111$ & 16.0 & 10 \\
\hline Allantoin & $\mathrm{C}_{4} \mathrm{H}_{6} \mathrm{~N}_{4} \mathrm{O}_{3}$ & 159 & 11 & $\mathrm{C}_{3} \mathrm{H}_{3} \mathrm{~N}_{2} \mathrm{O}_{2}^{+}$ & 99 & $61,73,81$ & 7.7 & 500 \\
\hline Carnitine & $\mathrm{C}_{7} \mathrm{H}_{15} \mathrm{NO}_{3}$ & 162 & 18 & $\mathrm{C}_{4} \mathrm{H}_{7} \mathrm{O}^{+}$ & 103 & $58,60,85$ & 7.2 & 0.5 \\
\hline Phenylalanine & $\mathrm{C}_{9} \mathrm{H}_{11} \mathrm{NO}_{2}$ & 166 & 28 & $\mathrm{C}_{8} \mathrm{H}_{7}^{+}$ & 103 & $77,91,120$ & 22 & 5 \\
\hline Pyridoxine & $\mathrm{C}_{8} \mathrm{H}_{11} \mathrm{NO}_{3}$ & 170 & 22 & $\mathrm{C}_{8}^{\circ} \mathrm{H}_{8} \mathrm{NO}^{+}$ & 134 & 152 & 7.9 & 0.1 \\
\hline Arginine & $\mathrm{C}_{6} \mathrm{H}_{14} \mathrm{~N}_{4} \mathrm{O}_{2}$ & 175 & 14 & $\mathrm{CH}_{6} \mathrm{~N}_{3}^{+}$ & 60 & $70,116,130$ & 5.8 & 1 \\
\hline $\mathrm{N}$-acetyl-ornithine & $\mathrm{C}_{7} \mathrm{H}_{14} \mathrm{~N}_{2} \mathrm{O}_{3}$ & 175 & 14 & $\mathrm{C}_{5} \mathrm{H}_{9} \mathrm{NO}_{2}{ }^{+}$ & 115 & 70,158 & 6.4 & 5 \\
\hline Citrulline & $\mathrm{C}_{6} \mathrm{H}_{13} \mathrm{~N}_{3} \mathrm{O}_{3}$ & 176 & 12 & $\mathrm{C}_{6} \mathrm{H}_{11} \mathrm{~N}_{2} \mathrm{O}_{3}{ }^{+}$ & 159 & 70,113 & 7.1 & 5 \\
\hline Allantoic acid & $\mathrm{C}_{4} \mathrm{H}_{8} \mathrm{~N}_{4} \mathrm{O}_{4}$ & 177 & 16 & $\mathrm{CH}_{5} \mathrm{~N}_{2} \mathrm{O}^{+}$ & 61 & 74,117 & $7.8,8.5$ & 10 \\
\hline Glucosamine & $\mathrm{C}_{6} \mathrm{H}_{13} \mathrm{NO}_{5}$ & 180 & 10 & $\mathrm{C}_{6} \mathrm{H}_{12} \mathrm{NO}_{4}^{+}$ & 162 & 72,84 & 5.7 & 10 \\
\hline Tyrosine & $\mathrm{C}_{9} \mathrm{H}_{11} \mathrm{NO}_{3}$ & 182 & 14 & $\mathrm{C}_{8} \mathrm{H}_{10} \mathrm{NO}^{+}$ & 136 & $77,91,119$ & $12.8,15.0$ & 10 \\
\hline Homocysteic acid & $\mathrm{C}_{4} \mathrm{H}_{9} \mathrm{NO}_{5} \mathrm{~S}$ & 184 & 13 & $\mathrm{C}_{3} \mathrm{H}_{8} \mathrm{NO}_{3} \mathrm{~S}^{+}$ & 138 & 56 & 8.8 & 10 \\
\hline 3-Phospho-serine & $\mathrm{C}_{3} \mathrm{H}_{8} \mathrm{NO}_{6} \mathrm{P}$ & 186 & 10 & $\mathrm{C}_{3} \mathrm{H}_{6} \mathrm{NO}_{2}^{+}$ & 88 & 42,70 & 8.7 & 5 \\
\hline $\mathrm{N}$-acetyl-glutamine & $\mathrm{C}_{7} \mathrm{H}_{12} \mathrm{~N}_{2} \mathrm{O}_{4}$ & 189 & 15 & $\mathrm{C}_{5} \mathrm{H}_{8} \mathrm{NO}_{3}{ }^{+}$ & 130 & 56,84 & $10.0,11.0$ & 10 \\
\hline Tryptophan & $\mathrm{C}_{11} \mathrm{H}_{12} \mathrm{~N}_{2} \mathrm{O}_{2}$ & 205 & 16 & $\mathrm{C}_{9} \mathrm{H}_{8} \mathrm{NO}^{+}$ & 146 & $91,115,118$ & 29.0 & 1 \\
\hline Pantothenic acid & $\mathrm{C}_{9} \mathrm{H}_{17} \mathrm{NO}_{5}$ & 220 & 20 & $\mathrm{C}_{3} \mathrm{H}_{8} \mathrm{NO}_{2}^{+}$ & 90 & 124,202 & 27.2 & 1 \\
\hline Cystathionine & $\mathrm{C}_{7} \mathrm{H}_{14} \mathrm{~N}_{2} \mathrm{O}_{4} \mathrm{~S}$ & 223 & 11 & $\mathrm{C}_{4} \mathrm{H}_{8} \mathrm{NO}_{2} \mathrm{~S}^{+}$ & 134 & 88 & 6.5 & 1 \\
\hline Deoxyuridine & $\mathrm{C}_{9} \mathrm{H}_{12} \mathrm{~N}_{2} \mathrm{O}_{5}$ & 229 & 11 & $\mathrm{C}_{4} \mathrm{H}_{5} \mathrm{~N}_{2} \mathrm{O}_{2}^{+}$ & 113 & 96 & 22.0 & 50 \\
\hline Thymidine & $\mathrm{C}_{10} \mathrm{H}_{14} \mathrm{~N}_{2} \mathrm{O}_{5}$ & 243 & 16 & $\mathrm{C}_{5} \mathrm{H}_{7} \mathrm{~N}_{2} \mathrm{O}^{+}$ & 127 & 109,110 & 27.0 & 5 \\
\hline Cytidine & $\mathrm{C}_{9} \mathrm{H}_{13} \mathrm{~N}_{3} \mathrm{O}_{5}$ & 244 & 12 & $\mathrm{C}_{4} \mathrm{H}_{6} \mathrm{~N}_{3} \mathrm{O}^{+}$ & 112 & 95 & 7.5 & 0.5 \\
\hline Biotin & $\mathrm{C}_{10} \mathrm{H}_{16} \mathrm{~N}_{2} \mathrm{O}_{3} \mathrm{~S}$ & 245 & 18 & $\mathrm{C}_{10} \mathrm{H}_{15} \mathrm{~N}_{2} \mathrm{O}_{2} \mathrm{~S}^{+}$ & $+\quad 227$ & 97 & 34.0 & 5 \\
\hline Uridine & $\mathrm{C}_{9} \mathrm{H}_{12} \mathrm{~N}_{2} \mathrm{O}_{6}$ & 245 & 15 & $\mathrm{C}_{4} \mathrm{H}_{5} \mathrm{~N}_{2} \mathrm{O}_{2}^{+}$ & 113 & 70,96 & $15.0,16.5$ & 10 \\
\hline Deoxyadenosine & $\mathrm{C}_{10} \mathrm{H}_{13} \mathrm{~N}_{5} \mathrm{O}_{3}$ & 252 & 20 & $\mathrm{C}_{5} \mathrm{H}_{6} \mathrm{~N}_{5}{ }^{+}$ & 136 & 119 & 24.9 & 1 \\
\hline Deoxyinosine & $\mathrm{C}_{10} \mathrm{H}_{12} \mathrm{~N}_{4} \mathrm{O}_{4}$ & 253 & 12 & $\mathrm{C}_{5} \mathrm{H}_{5} \mathrm{~N}_{4} \mathrm{O}^{+}$ & 137 & 119 & 26.2 & $\begin{array}{c}5 \\
\text { ontinued) }\end{array}$ \\
\hline
\end{tabular}


Table 1. Continued

\begin{tabular}{|c|c|c|c|c|c|c|c|c|}
\hline Compound $^{a}$ & $\begin{array}{l}\text { Neutral } \\
\text { formula }\end{array}$ & $\begin{array}{l}\text { Parent } \\
\text { mass }\end{array}$ & $\begin{array}{l}\text { Collision } \\
\text { energy } \\
(\mathrm{eV})\end{array}$ & $\begin{array}{l}\text { Preferred } \\
\text { product }^{\mathrm{b}}\end{array}$ & $\begin{array}{l}\text { Mass of } \\
\text { preferred } \\
\text { product }\end{array}$ & $\begin{array}{l}\text { Masses of } \\
\text { other major } \\
\text { products }^{c}\end{array}$ & $\begin{array}{c}\mathrm{RT}^{\mathrm{d}} \\
\text { (minutes) }\end{array}$ & $\begin{array}{c}\mathrm{LOD}^{\mathrm{e}} \\
(\mathrm{ng} / \mathrm{mL})\end{array}$ \\
\hline $\begin{array}{l}\text { Glucosamine-1- } \\
\text { phosphate }\end{array}$ & $\mathrm{C}_{6} \mathrm{H}_{14} \mathrm{NO}_{8} \mathrm{P}$ & 260 & 15 & $\mathrm{C}_{6} \mathrm{H}_{12} \mathrm{NO}_{4}^{+}$ & 162 & $72,84,144$ & 6.9 & 5 \\
\hline $\begin{array}{l}\text { Glucosamine-6- } \\
\text { phosphate }\end{array}$ & $\mathrm{C}_{6} \mathrm{H}_{14} \mathrm{NO}_{8} \mathrm{P}$ & 260 & 15 & $\mathrm{C}_{6} \mathrm{H}_{8} \mathrm{NO}_{2}^{+}$ & 126 & $84,98,108$ & 6.7 & 1 \\
\hline Thiamine & $\mathrm{C}_{12} \mathrm{H}_{16} \mathrm{~N}_{4} \mathrm{OS}$ & 265 & 17 & $\mathrm{C}_{6} \mathrm{H}_{8} \mathrm{~N}_{3}^{+}$ & 122 & 81,144 & 6.7 & 5 \\
\hline Deoxyguanosine & $\mathrm{C}_{10} \mathrm{H}_{13} \mathrm{~N}_{5} \mathrm{O}_{4}$ & 268 & 15 & $\mathrm{C}_{5} \mathrm{H}_{6} \mathrm{~N}_{5} \mathrm{O}^{+}$ & 152 & 110,135 & 26.2 & 5 \\
\hline Inosine & $\mathrm{C}_{10} \mathrm{H}_{12} \mathrm{~N}_{4} \mathrm{O}_{5}$ & 269 & 14 & $\mathrm{C}_{5} \mathrm{H}_{5} \mathrm{~N}_{4} \mathrm{O}^{+}$ & 137 & 110,119 & 25.2 & 1 \\
\hline Guanosine & $\mathrm{C}_{10} \mathrm{H}_{13} \mathrm{~N}_{5} \mathrm{O}_{5}$ & 284 & 33 & $\mathrm{C}_{5} \mathrm{H}_{3} \mathrm{~N}_{4} \mathrm{O}^{+}$ & 135 & 110,152 & 25.3 & 5 \\
\hline Xanthosine & $\mathrm{C}_{10} \mathrm{H}_{12} \mathrm{~N}_{4} \mathrm{O}_{6}$ & 285 & 20 & $\mathrm{C}_{5} \mathrm{H}_{5} \mathrm{~N}_{4} \mathrm{O}_{2}^{+}$ & 153 & 136 & 27.0 & 1 \\
\hline Glutathione-reduced & $\mathrm{C}_{10} \mathrm{H}_{17} \mathrm{~N}_{3} \mathrm{O}_{6} \mathrm{~S}$ & 308 & 19 & $\mathrm{C}_{5} \mathrm{H}_{8} \mathrm{NO}_{3} \mathrm{~S}^{+}$ & 162 & 76,84 & $7.8,10.5$ & 10 \\
\hline dCMP & $\mathrm{C}_{9} \mathrm{H}_{14} \mathrm{~N}_{3} \mathrm{O}_{7} \mathrm{P}$ & 308 & 16 & $\mathrm{C}_{4} \mathrm{H}_{6} \mathrm{~N}_{3} \mathrm{O}^{+}$ & 112 & 81 & 7.8 & 5 \\
\hline dUMP & $\mathrm{C}_{9} \mathrm{H}_{13} \mathrm{~N}_{2} \mathrm{O}_{8} \mathrm{P}$ & 309 & 11 & $\mathrm{C}_{5} \mathrm{H}_{5} \mathrm{O}^{+}$ & 81 & 53 & 23.6 & 10 \\
\hline $\begin{array}{l}\text { Thymidine } \\
\text { monophosphate }\end{array}$ & $\mathrm{C}_{10} \mathrm{H}_{15} \mathrm{~N}_{2} \mathrm{O}_{8} \mathrm{P}$ & 323 & 17 & $\mathrm{C}_{5} \mathrm{H}_{5} \mathrm{O}^{+}$ & 81 & 53,127 & 27 & 5 \\
\hline CMP & $\mathrm{C}_{9} \mathrm{H}_{14} \mathrm{~N}_{3} \mathrm{O}_{8} \mathrm{P}$ & 324 & 16 & $\mathrm{C}_{4} \mathrm{H}_{6} \mathrm{~N}_{3} \mathrm{O}^{+}$ & 112 & 95 & 7.8 & 0.5 \\
\hline UMP & $\mathrm{C}_{9} \mathrm{H}_{13} \mathrm{~N}_{2} \mathrm{O}_{9} \mathrm{P}$ & 325 & 12 & $\mathrm{C}_{5} \mathrm{H}_{5} \mathrm{O}_{2}^{+}$ & 97 & 69,113 & 16.2 & 10 \\
\hline cyclic-AMP & $\mathrm{C}_{10} \mathrm{H}_{12} \mathrm{~N}_{5} \mathrm{O}_{6} \mathrm{P}$ & 330 & 26 & $\mathrm{C}_{5} \mathrm{H}_{6} \mathrm{~N}_{5}+$ & 136 & 119,312 & 26.5 & 1 \\
\hline dAMP & $\mathrm{C}_{10} \mathrm{H}_{14} \mathrm{~N}_{5} \mathrm{O}_{6} \mathrm{P}$ & 332 & 21 & $\mathrm{C}_{5} \mathrm{H}_{6} \mathrm{~N}_{5}^{+}$ & 136 & 81 & 18.0 & 5 \\
\hline Thiamine-phosphate & $\mathrm{C}_{12} \mathrm{H}_{17} \mathrm{~N}_{4} \mathrm{O}_{4} \mathrm{PS}$ & 345 & 13 & $\mathrm{C}_{6} \mathrm{H}_{8} \mathrm{~N}_{3}^{+}$ & 122 & $81,126,224$ & 7.6 & 5 \\
\hline AMP & $\mathrm{C}_{10} \mathrm{H}_{14} \mathrm{~N}_{5} \mathrm{O}_{7} \mathrm{P}$ & 348 & 21 & $\mathrm{C}_{5} \mathrm{H}_{6} \mathrm{~N}_{5}^{+}$ & 136 & 97,119 & $12.4,13.5$ & 10 \\
\hline dGMP & $\mathrm{C}_{10} \mathrm{H}_{14} \mathrm{~N}_{5} \mathrm{O}_{7} \mathrm{P}$ & 348 & 36 & $\mathrm{C}_{5} \mathrm{H}_{3} \mathrm{~N}_{4} \mathrm{O}^{+}$ & 135 & $81,110,152$ & 25.3 & 5 \\
\hline $\begin{array}{l}\text { Inosine } \\
\text { monophosphate }\end{array}$ & $\mathrm{C}_{10} \mathrm{H}_{13} \mathrm{~N}_{4} \mathrm{O}_{8} \mathrm{P}$ & 349 & 19 & $\mathrm{C}_{5} \mathrm{H}_{5} \mathrm{~N}_{4} \mathrm{O}^{+}$ & 137 & 97,119 & 23.8 & 10 \\
\hline GMP & $\mathrm{C}_{10} \mathrm{H}_{14} \mathrm{~N}_{5} \mathrm{O}_{8} \mathrm{P}$ & 364 & 19 & $\mathrm{C}_{5} \mathrm{H}_{6} \mathrm{~N}_{5} \mathrm{O}^{+}$ & 152 & 110,135 & 20.8 & 10 \\
\hline $\begin{array}{l}\text { Xanthosine-5- } \\
\text { phosphate }\end{array}$ & $\mathrm{C}_{10} \mathrm{H}_{13} \mathrm{~N}_{4} \mathrm{O}_{9} \mathrm{P}$ & 365 & 11 & $\mathrm{C}_{5} \mathrm{H}_{5} \mathrm{O}_{2}^{+}$ & 97 & 153 & 25.2 & 10 \\
\hline Riboflavin & $\mathrm{C}_{17} \mathrm{H}_{20} \mathrm{~N}_{4} \mathrm{O}_{6}$ & 377 & 24 & $\mathrm{C}_{12} \mathrm{H}_{11} \mathrm{~N}_{4} \mathrm{O}_{2}^{+}$ & 243 & $145,172,198$ & 34.5 & 5 \\
\hline $\begin{array}{l}\text { S-adenosyl- } \\
\text { homocysteine }\end{array}$ & $\mathrm{C}_{14} \mathrm{H}_{20} \mathrm{~N}_{6} \mathrm{O}_{5} \mathrm{~S}$ & 385 & 19 & $\mathrm{C}_{5} \mathrm{H}_{6} \mathrm{~N}_{5}^{+}$ & 136 & $88,134,250$ & 7.8 & 10 \\
\hline $\begin{array}{l}S \text {-adenosyl- } \\
\text { methionine }\end{array}$ & $\mathrm{C}_{15} \mathrm{H}_{22} \mathrm{~N}_{6} \mathrm{O}_{5} \mathrm{~S}$ & 399 & 13 & $\mathrm{C}_{10} \mathrm{H}_{12} \mathrm{~N}_{5} \mathrm{O}_{3}^{+}$ & 250 & $97,102,136$ & 5.8 & 10 \\
\hline Folate & $\mathrm{C}_{19} \mathrm{H}_{19} \mathrm{~N}_{7} \mathrm{O}_{6}$ & 442 & 16 & $\mathrm{C}_{14} \mathrm{H}_{11} \mathrm{~N}_{6} \mathrm{O}_{2}^{+}$ & 295 & 120,176 & 33.5 & 1 \\
\hline DHF & $\mathrm{C}_{19} \mathrm{H}_{21} \mathrm{~N}_{7} \mathrm{O}_{6}$ & 444 & 30 & $\mathrm{C}_{7} \mathrm{H}_{8} \mathrm{~N}_{5} \mathrm{O}^{+}$ & 178 & 136,161 & 33.0 & N/A \\
\hline THF & $\mathrm{C}_{19} \mathrm{H}_{23} \mathrm{~N}_{7} \mathrm{O}_{6}$ & 446 & 41 & $\mathrm{C}_{7} \mathrm{H}_{6} \mathrm{NO}^{+}$ & 120 & 166,299 & 27.0 & N/A \\
\hline 5-methyl-THF & $\mathrm{C}_{20} \mathrm{H}_{25} \mathrm{~N}_{7} \mathrm{O}_{6}$ & 460 & 19 & $\mathrm{C}_{15} \mathrm{H}_{17} \mathrm{~N}_{6} \mathrm{O}_{2}^{+}$ & 313 & $152,180,194$ & 27.4 & $\mathrm{~N} / \mathrm{A}$ \\
\hline $\begin{array}{l}\text { Glutathione- } \\
\text { oxidized }\end{array}$ & $\mathrm{C}_{20} \mathrm{H}_{32} \mathrm{~N}_{6} \mathrm{O}_{12} \mathrm{~S}_{2}$ & 2613 & 33 & $\mathrm{C}_{8} \mathrm{H}_{11} \mathrm{~N}_{2} \mathrm{O}_{2} \mathrm{~S}_{2}{ }^{+}$ & 231 & 355,484 & 7.8 & 10 \\
\hline
\end{tabular}

dCMP, 2'-deoxycytidine-5'-monophosphate; dUMP, 2'-deoxyuridine 5'-monophosphate; CMP, cytidine-5'-monophosphate; UMP, uridine-5'-monophosphate; cyclic-AMP, adenosine-3',5'-cyclic-monophosphate; dAMP, 2'-deoxyadenosine-5'-monophosphate; AMP, adenosine-5'-monophosphate; dGMP, 2'-deoxyguanosine-5'-monophosphate; DHF, 7,8-dihydrofolate; THF, 5,6,7,8-tetrahydrofolate; 5-methyl-THF, 5-methyl-5,6,7,8-tetrahydrofolate. Isoleucine and leucine are not separated in the present LC-MS/MS method and therefore are listed together.

${ }^{a}$ Compounds are listed in the order of their molecular weight.

bThe preferred product was selected primarily to maximize signal-to-noise; in certain cases, it also was selected to avoid interference from other compounds that have same parent mass and retention time.

${ }^{\mathrm{c}} \mathrm{N} / \mathrm{A}$, not applicable as only a single major product is formed.

${ }^{d} \mathrm{RT}$, retention time. Typical run-to-run variability in $\mathrm{RT}$ is $\pm 0.3 \mathrm{~min}$. In the case of split peaks, the RT for the highest-intensity peak is marked in bold. eThe LOD is defined as the lowest concentration at which the signal-to-noise ratio is larger than 5. Information on DHF, THF, and 5-methyl-THF are not available because of their poor stability.

\section{Optimization of MS/MS Fragmentation}

For the purpose of SRM analysis, it is necessary to determine the fragmentation products of each metabolite parent (precursor) ion. A $1-\mu \mathrm{g} / \mathrm{mL}$ working solution of each metabolite was infused into the mass spectrometer at a flow rate of $20 \mu \mathrm{L} / \mathrm{min}$. The mass spectrometer was first operated in Q1MS mode to confirm detection of the parent ion. It was then operated in MS/MS mode to look for the product ions for the selected parent. The "compound optimization" feature of the Quantum Tune Master software was used to construct graphs of product ion signal as a function of collision energy (CE) for each of the four most-abundant product ions. These graphs were then used to determine the optimized CE to produce each product ion. These optimized CEs were then used to conduct SRM monitoring for each product ion during an LC-MS/MS run.

\section{Optimization of LC-MS/MS Conditions}

LC conditions were optimized for groups of 10 or more compounds at a time, by incorporating multiple SRMs 
in a single LC-MS/MS method. HPLC variables explored included column, the mobile phase composition (solvent, $\mathrm{pH}$ ), flow rate, and gradient. Columns tested (all $250 \times 2 \mathrm{~mm}$ from Phenomenex, Torrance, CA) were Synergi $4 \mu \mathrm{m}$ Fusion-RP 80A (polar-embedded C18 with trimethyl siloxane endcapping), Synergi $4 \mu \mathrm{m}$ Hydro-RP 80A (C18 with polar end-capping), Synergi 4 $\mu \mathrm{m}$ Polar-RP 80A (ether-linked phenyl with polar endcapping), and Luna $3 \mu \mathrm{m} \mathrm{C18(2)} \mathrm{100A} \mathrm{(standard} \mathrm{C18).}$ The organic solvents tested included methanol and acetonitrile, with $\mathrm{pH}$ set by addition of formic acid, acetic acid, ammonium formate, or ammonium acetate. Overall performance for most of the 90 compounds (as measured largely by signal-to-noise) was best for the Fusion-RP column with water/methanol/0.1\% formic acid. In general, similar results were obtained with all of the tested columns, with, for most compounds, methanol/water/formic acid giving better signal-to-noise than other mobile phases. The optimized LC conditions used for all subsequent work were as follows: Solvent A, water with $0.1 \%$ formic acid; Solvent B, methanol with $0.1 \%$ formic acid; Fusion-RP column; column equilibration time in $97 \%$ Solvent $A / 3 \%$ Solvent $B \geq 8$ min before all injections; elution gradient, $0 \mathrm{~min}-3 \% \mathrm{~B}$; $8 \mathrm{~min}-3 \% \mathrm{~B} ; 38 \mathrm{~min}-95 \% \mathrm{~B} ; 45 \mathrm{~min}-95 \% \mathrm{~B} ; 47$ $\min -3 \%$ B; $55 \min -3 \%$ B.

After fixing the chromatography conditions, the retention time for each compound was determined and an LC-MS/MS method capable of detecting all 90 compounds in a single run was developed. A constraint in developing this method was that the Finnigan TSQ Quantum Ultra triple-quadrupole mass spectrometer software limits SRM scanning to a maximum of 64 different scans in any time period. Thus, it was not possible to scan through the SRMs of all 90 compounds throughout the entire 55-min LC-MS/MS run duration. Instead, the run duration was divided into four different time segments $(0-12,12-20,20-30$, and 30-55 min; boundaries between these segments are indicated by dashed lines on Figure 1), with the SRM scans conducted within each time segment limited to those corresponding to compounds eluting during that time segment (e.g., for orotic acid, which elutes at $16 \mathrm{~min}$, its corresponding SRM scan of $\mathrm{m} / \mathrm{z} 157 \rightarrow 68$ is conducted only during the second time segment, from 12 to 20 min). For compounds eluting at the boundaries between time segments, the SRM scan corresponding to the compound is conducted in both time segments.

\section{Challenges Associated With Compounds of Identical Nominal Mass}

Quadrupole mass spectrometry generally does not have enough resolving power to distinguish compounds that have identical nominal masses, even if they have different accurate masses. Nevertheless, in the LC-MS/MS analysis, it often is possible to achieve high specificity by the combination of characteristic SRM transitions

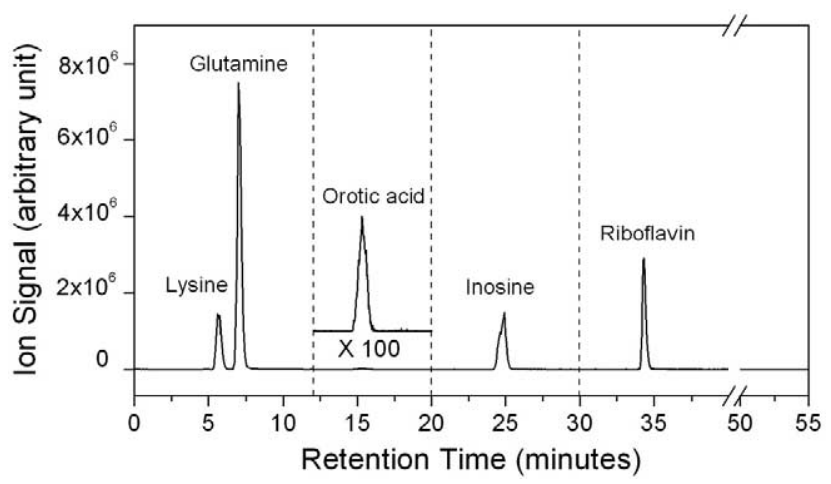

Figure 1. Representative LC-MS/MS results for purified compound standards (500 ng/mL). Dashed lines demarcate segments of the LC-MS/MS run during which different sets of SRM scans are performed. For simplicity, the figure shows results for only a single SRM scan event in each time segment: in the first segment $\mathrm{SRM} m / z 147 \rightarrow 84$, which detects lysine and glutamine; in the second segment SRM $m / z 157 \rightarrow 68$, which detects orotic acid; in the third segment SRM $m / z 269 \rightarrow 137$, which detects inosine; and in the fourth segment SRM $m / z 377 \rightarrow 243$, which detects riboflavin.

and chromatographic separation. Here, we briefly discuss specific challenges that we faced in developing the present method with distinguishing compounds of identical nominal mass. Isoleucine and leucine are structural isomers that exhibit similar fragmentation patterns and overlapping chromatography peaks; thus, we could not distinguish them. Threonine and homoserine are isomers that co-elute chromatographically but have certain distinctive product ions: $120 \rightarrow 57$ for threonine and $120 \rightarrow 44$ for homoserine and are distinguished on that basis. We were similarly able to distinguish the following other compounds based on their fragmentation: glucosamine-1-phosphate $(260 \rightarrow 162)$ versus glucoasmine-6-phosphate $(260 \rightarrow 126)$ and reduced glutathione $(308 \rightarrow 162)$ versus $2^{\prime}$-deoxycytidine$5^{\prime}$-monophosphate $(\mathrm{dCMP})(308 \rightarrow 112)$. Lysine and glutamine form positive ions of $\mathrm{m} / \mathrm{z} 147$; however, they are chromatographically well separated in the current method and are distinguished on that basis. We were similarly able to distinguish the following other compounds chromatographically: ornithine versus asparagine, $p$-aminobenzoic acid versus anthranilic acid, glutamate versus acetyl-serine, arginine versus $N$ acetyl-ornithine, biotin versus uridine, and adenosine-5'-monophosphate versus 2 ' deoxyguanosine- 5 'monophosphate.

\section{Method Validation for Purified Metabolites}

The validity of our LC-MS/MS method was explored with respect to compound stability, method reproducibility, limit of detection (LOD), and linearity. For stability studies on purified compounds, metabolite solution at a concentration of $500 \mathrm{ng} / \mathrm{mL}$, with reserpine at $50 \mathrm{ng} / \mathrm{mL}$ as internal standard, in 50:50 methanol/water with $0.1 \%$ formic acid, was prepared. The 
solution was split into four parts. One was analyzed immediately. Others were stored separately at -80 , -20 , and $4{ }^{\circ} \mathrm{C}$. These samples were analyzed after 1 week to evaluate the 1-week stability. Normalized signals, corresponding to the peak height of the metabolite signal divided by the peak height of the internal standard signal, were compared for the various storage conditions. In the present study, a compound is considered stable at a specified temperature if the normalized signal after storage is within $\pm 15 \%$ of the original normalized signal.

For reproducibility studies, mixed standard solutions containing all 90 metabolites, each at $500 \mathrm{ng} / \mathrm{mL}$, and using reserpine at $50 \mathrm{ng} / \mathrm{mL}$ as internal standard, were prepared and split into three parts and stored at $-80{ }^{\circ} \mathrm{C}$. The first sample was analyzed four times on Day 1 . The remaining two samples were analyzed on Days 2 and 3, four times in each case.

To determine the method's linearity and LOD, mixtures of the standard compounds at various concentrations $(2000,1000,500,100,50,10,5,1,0.5$, and 0.1 $\mathrm{ng} / \mathrm{mL}$ ) were prepared and studied. For linearity analysis, the resulting data were analyzed by linear regression. For LOD analysis, the results were compared with that of blank 50:50 methanol/water with $0.1 \%$ formic acid. The LOD was defined as the lowest concentration at which the signal-to-noise ratio, as defined by $(C-$ $B) / M$, where $C$ is compound peak height, $B$ is background height, and $M$ is maximum peak to trough height of the noise, was at least 5 .

\section{Determination of the Carbon Count of Product Ions}

To enable quantitative comparison of isotope-labeled versus isotope-unlabeled cellular extracts based on ${ }^{12} \mathrm{C} /$ ${ }^{13} \mathrm{C}$-peak ratios, it is necessary to know the number of carbon atoms in parent ions and product ions. Although the molecular structures of the parent ions are known, those of the product ions generally are not known, because collision-induced fragmentation/dissociation can be complicated, especially when internal rearrangement is involved. We used several complementary approaches to dissect the structure of the product ions. First, we referred to available literature, which is especially comprehensive with respect to amino acid fragmentation [27-31] and contains information on the fragmentation of numerous other metabolites [32-37]. Second, when literature regarding fragmentation of specific metabolites of interest was not available, we inferred the likely fragment lost based on the change in molecular weight, using the following heuristic: $17=$ $\mathrm{NH}_{3} ; 18=\mathrm{H}_{2} \mathrm{O} ; 42=\mathrm{CH}_{2} \mathrm{CO} ; 43=\mathrm{HNCO} ; 46=\mathrm{H}_{2} \mathrm{O}$ $+\mathrm{CO}$. Finally, when possible (i.e., for the $36 \mathrm{com}-$ pounds listed in Table 2), the number of the carbon atoms in the product ion was determined using ${ }^{13} \mathrm{C}$ labeled metabolite produced in bacteria fed ${ }^{13} \mathrm{C}$-glucose.

\section{Bacterial Strain and Culture Conditions}

Salmonella enterica LT2 strain TR10000 was used for all biological experiments. The cells were grown in M9 media containing a final concentration of $10 \mathrm{mM}$ of $\mathrm{NH}_{4} \mathrm{Cl}, 5.6 \mathrm{mM}$ of glucose (unlabeled or ${ }^{13} \mathrm{C}$-labeled, as indicated), $0.1 \mathrm{mM}$ of $\mathrm{CaCl}_{2}, 2 \mathrm{mM}$ of $\mathrm{MgSO}_{4}, 48 \mathrm{mM}$ of $\mathrm{Na}_{2} \mathrm{HPO}_{4}, 22$ of $\mathrm{mM} \mathrm{KH}_{2} \mathrm{PO}_{4}$, and $8.6 \mathrm{mM}$ of $\mathrm{NaCl}$.

Exponential-phase cultures were produced by growing bacteria to saturation in $5 \mathrm{~mL}$ of the $\mathrm{M} 9$ media on a roller at $37^{\circ} \mathrm{C}$ for approximately $14 \mathrm{~h}$ and then diluting the saturated culture tenfold into $50 \mathrm{~mL}$ of $\mathrm{M} 9$ media in a 250-mL flask. This diluted culture was then grown on a shaker at $37^{\circ} \mathrm{C}$ until in exponential phase, i.e., optical density at $650 \mathrm{~nm}\left(\mathrm{OD}_{650}\right)$ of $\sim 0.35$ and then the extracts were prepared as described in the following paragraphs. For producing uniformly ${ }^{13} \mathrm{C}$-labeled extracts, cultures were grown to saturation at least twice in ${ }^{13} \mathrm{C}$-glucose to ensure nearly complete turnover of all carbon atoms before initiating the final culture, which was collected in exponential phase $\left(\mathrm{OD}_{650} \sim 0.35\right)$. Stationary-phase cultures were produced by allowing diluted cultures to grow on a shaker at $37{ }^{\circ} \mathrm{C}$ for approximately $28 \mathrm{~h}$, resulting in $\mathrm{OD}_{650} \sim 0.55$. The growth of the stationary-phase cultures was limited by availability of usable carbon, as indicated by the fact that cultures grown in double the amount of glucose reached a substantially higher $\mathrm{OD}_{650}$ before entering stationary phase.

\section{Metabolite Extraction}

Bacteria were separated from media by centrifugation for $6 \mathrm{~min}$ at $3000 \times g$ and $23{ }^{\circ} \mathrm{C}$. Immediately on completion of spin, the supernatant was discarded and $300 \mu \mathrm{L}$ of $80: 20$ methanol/water with $50 \mathrm{ng} / \mathrm{mL}$ of reserpine as internal standard at dry-ice temperature $\left(-75^{\circ} \mathrm{C}\right)$ was added to the pellet and vortexed to mix. The cell suspension was then allowed to sit on dry ice for $15 \mathrm{~min}$. At the end of the $15 \mathrm{~min}$, the sample was spun in a microcentrifuge at 13,200 rpm for 5 min at 4 ${ }^{\circ} \mathrm{C}$. The soluble extract was then removed and placed on dry ice and the pellet was resuspended in $200 \mu \mathrm{L}$ of the same 80:20 methanol/water solution by vortexing. This suspension was then placed on dry ice for $15 \mathrm{~min}$ before being again centrifuged to yield a second clear extract, which was combined with the first extract. The pellet was again resuspended in the same 80:20 methanol/ water solution by vortexing and the resulting suspension was sonicated in an ice bath for 15 min using a FS30H Ultrasonic Cleaner (Fisher Scientific) with a power of $100 \mathrm{~W}$ at $42 \mathrm{kHz}$ (note: very similar results also were obtained without sonication). Once the 15 min was complete, the sample was again spun down and the resulting extract was combined with the initial two extracts.

To explore the efficiency of the foregoing serial extraction procedure, the pellet of cellular material collected after the third extraction step by centrifuga- 
Table 2. LC-MS/MS results for 36 compounds that can be detected without interference from $S$. enterica bacterial extract

\begin{tabular}{|c|c|c|c|c|c|}
\hline Compound & $\begin{array}{c}\text { Parent } \\
\text { mass }\end{array}$ & $\begin{array}{c}\text { CE } \\
(\mathrm{eV})\end{array}$ & $\begin{array}{c}\text { Product } \\
\text { mass }\end{array}$ & $\begin{array}{c}{ }^{12} \text { C-signal } \\
\left(\text { noise }^{\mathrm{a}}\right)\end{array}$ & $\begin{array}{c}{ }^{13} \mathrm{C} \text {-signal } \\
\left.\text { (noise }{ }^{\mathrm{a}}\right)\end{array}$ \\
\hline Glycine & 76 & 16 & 30 & $4.98 \mathrm{E} 3(5.7 \%)$ & $9.64 \mathrm{E} 3(<0.1 \%)$ \\
\hline Putrescine & 89 & 11 & 72 & 6.77E5 (0.2\%) & $8.33 \mathrm{E} 5(<0.1 \%)$ \\
\hline Alanine & 90 & 11 & 44 & $1.00 \mathrm{E} 6(0.4 \%)$ & $1.36 \mathrm{E} 6(<0.1 \%)$ \\
\hline Proline & 116 & 11 & 70 & 1.66E5 (0.4\%) & $2.10 \mathrm{E} 5(0.3 \%)$ \\
\hline Valine & 118 & 11 & 55 & $2.22 \mathrm{E} 5(<0.1 \%)$ & $2.59 \mathrm{E} 5(<0.1 \%)$ \\
\hline Threonine & 120 & 30 & 57 & $2.42 \mathrm{E} 3(1.7 \%)$ & $3.97 \mathrm{E} 3(0.3 \%)$ \\
\hline Isoleucine/Leucine & 132 & 11 & 86 & $2.20 \mathrm{E} 5(1.3 \%)$ & $3.08 \mathrm{E} 5(<0.1 \%)$ \\
\hline Aspartic Acid & 134 & 15 & 74 & 3.37E4 (2.6\%) & $3.20 \mathrm{E} 4(<0.1 \%)$ \\
\hline Hypoxanthine & 137 & 19 & 110 & $1.80 \mathrm{E} 4(0.8 \%)$ & $2.55 \mathrm{E} 4(2.6 \%)$ \\
\hline Anthranilic acid & 138 & 20 & 92 & $2.06 \mathrm{E} 3(22.3 \%)$ & 1.07E3 (3.7\%) \\
\hline Glutamine & 147 & 15 & 84 & 1.37E6 $(<0.1 \%)$ & $1.92 \mathrm{E} 6(<0.1 \%)$ \\
\hline Glutamate & 148 & 15 & 84 & $9.28 \mathrm{E} 6(<0.1 \%)$ & $1.07 E 7(<0.1 \%)$ \\
\hline O-Acetyl-L-serine & 148 & 12 & 106 & 5.00E3 $(6.7 \%)$ & $9.57 \mathrm{E} 3(3.2 \%)$ \\
\hline Methionine & 150 & 10 & 133 & $3.19 \mathrm{E} 4(1.3 \%)$ & $3.95 \mathrm{E} 4(1.5 \%)$ \\
\hline Phenylalanine & 166 & 28 & 103 & $3.10 \mathrm{E} 4(0.8 \%)$ & $3.48 \mathrm{E} 4(2.2 \%)$ \\
\hline Arginine & 175 & 14 & 60 & 1.16E4 (0.1\%) & $6.21 \mathrm{E} 3(0.2 \%)$ \\
\hline Citrulline & 176 & 12 & 159 & $3.21 \mathrm{E} 5(0.4 \%)$ & $2.29 \mathrm{E} 5(0.3 \%)$ \\
\hline Tyrosine & 182 & 14 & 136 & 7.36E4 (1.8\%) & $8.34 \mathrm{E} 4(<0.1 \%)$ \\
\hline Tryptophan & 205 & 16 & 146 & $3.31 \mathrm{E} 5(0.7 \%)$ & $3.67 E 5(<0.1 \%)$ \\
\hline Pantothenic acid & 220 & 20 & 90 & 1.47E4 $(0.2 \%)$ & $2.00 \mathrm{E} 4(1.4 \%)$ \\
\hline Glucosamine-6-phosphate & 260 & 15 & 126 & 4.53E3 $(6.0 \%)$ & $6.33 \mathrm{E} 3(0.3 \%)$ \\
\hline Deoxyguanosine & 268 & 15 & 152 & $9.40 \mathrm{E} 3(9.2 \%)$ & 1.05E4 $(0.2 \%)$ \\
\hline Inosine & 269 & 14 & 137 & $1.33 \mathrm{E} 5(0.6 \%)$ & 1.07E5 $(<0.1 \%)$ \\
\hline Xanthosine & 285 & 20 & 153 & 8.79E3 (1.3\%) & 1.09E4 $(<0.1 \%)$ \\
\hline Glutathione-reduced & 308 & 19 & 162 & $3.29 \mathrm{E} 6(<0.1 \%)$ & $3.26 \mathrm{E} 6(<0.1 \%)$ \\
\hline dCMP & 308 & 16 & 112 & $5.86 \mathrm{E} 4(<0.1 \%)$ & 7.93E4 $(<0.1 \%)$ \\
\hline Thymidine monophosphate & 323 & 17 & 81 & $3.26 \mathrm{E} 4(0.5 \%)$ & 4.08E4 (0.4\%) \\
\hline CMP & 324 & 16 & 112 & $1.23 \mathrm{E} 5(<0.1 \%)$ & $1.34 \mathrm{E} 5(<0.1 \%)$ \\
\hline UMP & 325 & 12 & 97 & 4.66E4 (0.6\%) & $5.39 \mathrm{E} 4(<0.1 \%)$ \\
\hline Cyclic AMP & 330 & 26 & 136 & $2.21 \mathrm{E} 4(2.0 \%)$ & $3.15 \mathrm{E} 4(<0.1 \%)$ \\
\hline dAMP & 332 & 21 & 136 & $2.20 \mathrm{E} 4(0.2 \%)$ & $2.66 \mathrm{E} 4(0.1 \%)$ \\
\hline AMP & 348 & 21 & 136 & $7.90 \mathrm{E} 5(<0.1 \%)$ & $9.13 \mathrm{E} 5(<0.1 \%)$ \\
\hline Inosine monophosphate & 349 & 19 & 137 & 1.34E5 (<0.1\%) & $1.71 \mathrm{E} 5(<0.1 \%)$ \\
\hline Riboflavin & 377 & 24 & 243 & $1.78 \mathrm{E} 5(<0.1 \%)$ & $2.58 \mathrm{E} 5(<0.1 \%)$ \\
\hline S-Adenosyl-methionine & 399 & 13 & 250 & $1.35 \mathrm{E} 5(<0.1 \%)$ & $7.62 \mathrm{E} 4(1.6 \%)$ \\
\hline Glutathione-oxidized & 613 & 33 & 231 & $7.92 \mathrm{E} 4(<0.1 \%)$ & 8.03E4 $(<0.1 \%)$ \\
\hline
\end{tabular}

dCMP, 2'-deoxycytidine-5'-monophosphate; CMP, cytidine-5'-monophosphate; UMP, uridine-5'-monophosphate; AMP, adenosine-5'-monophosphate; dAMP, 2'-deoxyadenosine-5'- monophosphate.

${ }^{a}$ The term ${ }^{12} \mathrm{C}$-noise refers to the ${ }^{12} \mathrm{C}$-signal for cells grown in ${ }^{13} \mathrm{C}$-glucose; the term ${ }^{13} \mathrm{C}$-noise is analogously the ${ }^{13} \mathrm{C}$-signal for cells grown in unlabeled glucose.

See Table 1 for abbreviation meanings.

tion was reextracted at $4{ }^{\circ} \mathrm{C}$ with sonication for $15 \mathrm{~min}$ with a variety of different solvents. Each solvent was tested in an independent tube containing a pellet of the already extracted cellular material. The solvents were as follows: (1) 80:20 methanol/water ("methanol"), (2) 80:20 ethanol/water ("ethanol"), (3) 80:20 methanol/ water $+1 \%$ formic acid ("acidic methanol"), (4) 80:20 methanol/water $+1 \%$ ammonium hydroxide ("basic methanol"), and (5) 67:33 chloroform/methanol ("chloroform/methanol"). After the 15-min extraction period, the samples were spun in the microcentrifuge to yield clear extracts. Before LC-MS/MS analysis, the "basic methanol" extract was neutralized by addition of formic acid and the "chloroform/methanol" extract was dried and resuspended in 80:20 methanol/water. The resulting solutions were analyzed as usual by LCMS/MS with SRMs designed to detect 27 of the 36 compounds listed in Table 2 (omitted for suboptimal signal-to-noise and/or historical reasons: glycine, acetyl-serine, phenylalanine, arginine, tyrosine, glucosamine-6-phosphate, dCMP, thymidine monophosphate, UMP.

\section{Method Development for Bacterial Extracts}

The LC-MS/MS method described previously, having been validated with respect to its performance for purified metabolites, was tested on bacterial cell extracts (exponential phase). Extracts from bacteria grown both in unlabeled $\left({ }^{12} \mathrm{C}-\right)$ and (with appropriate modification of the SRMs to account for the molecular weight increase) ${ }^{13} \mathrm{C}$-glucose were tested. Approximately $50 \%$ of the metabolites failed to give a specific and reproducible signal from the bacterial cell extracts, indicating that many of these metabolites are present in the bacterial extracts in low amounts. For a smaller number 
of metabolites, interfering peaks arising from other biological materials were present either in ${ }^{12} \mathrm{C}$ - or in ${ }^{13} \mathrm{C}$-grown bacterial extracts and precluded reliable analysis. Therefore, analysis of bacterial extracts focused on 36 compounds for which both ${ }^{12} \mathrm{C}$ - and ${ }^{13} \mathrm{C}$-grown cells showed readily detectable peaks without interferences. A method involving 72 SRMs corresponding to the ${ }^{12} \mathrm{C}$ - and ${ }^{13} \mathrm{C}$-forms of these 36 metabolites (divided as described previously into segments) was developed accordingly.

\section{Method Validation for Bacterial Extracts}

The validity of the bacterial extract analysis method was explored with respect to peak identity and quantitative reproducibility. Confirmation that an observed peak in a biological extract corresponded to a particular metabolite was obtained by spiking a ${ }^{13} \mathrm{C}$-labeled biological extract with $100 \mathrm{ng} / \mathrm{mL}$ of purified metabolite (not isotope labeled) and checking that the purified standard coeluted with the peak from the biological extract. In addition, it was confirmed that the height of the ${ }^{12} \mathrm{C}$-peak from a culture grown in unlabeled glucose $\left({ }^{12} \mathrm{C}\right.$-culture) was much greater than that of the ${ }^{12} \mathrm{C}$ peak from a culture grown in ${ }^{13} \mathrm{C}$-labeled glucose $\left({ }^{13} \mathrm{C}\right.$-culture), and likewise for the ${ }^{13} \mathrm{C}$-peak. Finally, it was confirmed that the height of the ${ }^{12} \mathrm{C}$-peak from a ${ }^{12} \mathrm{C}$-culture was comparable with that of the ${ }^{13} \mathrm{C}$-peak from an identical ${ }^{13} \mathrm{C}$-culture.

The reproducibility of ${ }^{12} \mathrm{C} /{ }^{13} \mathrm{C}$-ratio measurements in mixtures of ${ }^{12} \mathrm{C}$ - and ${ }^{13} \mathrm{C}$-extracts was determined by repeatedly growing exponential-phase ${ }^{12} \mathrm{C}$-cultures and ${ }^{13} \mathrm{C}$-cultures, preparing the corresponding extracts, and mixing these extracts in the ratio of 10 parts ${ }^{12} \mathrm{C}$-extract to 1 part ${ }^{13} \mathrm{C}$-extract. The resulting extract mixtures were then analyzed by LC-MS/MS multiple times, to enable determination of both within-sample and between-sample ratio measurement reproducibility.

\section{Comparison of the Metabolomes of Exponential versus Stationary-Phase Bacteria}

Both exponential- and stationary-phase cultures were grown as described above. The bacterial doubling time during exponential phase was approximately $65 \mathrm{~min}$ (except in a single case where the doubling time was approximately $2 \mathrm{~h}$ and the culture was accordingly excluded from analysis). Extracts were then prepared, mixed with one-tenth their volume of exponentialphase control extract $\left({ }^{13} \mathrm{C}\right.$-labeled), and analyzed to yield the ${ }^{12} \mathrm{C} /{ }^{13} \mathrm{C}$-ratio. Certain extract samples were analyzed multiple times by LC-MS/MS, in which case the mean ratio was taken as the value for that extract. The ratios were corrected for the density of the cultures from which they were derived, by normalizing to the target exponential density of $\mathrm{OD}_{650}=0.35$ (i.e., if the observed $\mathrm{OD}$ in the ${ }^{12} \mathrm{C}$-culture was 0.32 , then the observed ratio was multiplied by $0.35 / 0.32$; all expo- nential-phase cultures were collected at an OD between 0.3 and 0.35 and all stationary-phase cultures were collected at an OD between 0.51 and 0.65 ). The logarithm (base 2) of the normalized ${ }^{12} \mathrm{C} /{ }^{13} \mathrm{C}$-ratio for each extract mix was then taken, and the mean log ratio was determined for the exponential-phase $(n=4)$ and the stationary-phase $(n=4)$ cultures. The mean log ratio was then compared between the exponential- and stationary-phase cultures for each metabolite using a twotailed student's $t$-test.

\section{Absolute Quantitation of Bacterial Glutamate and Glutamine}

Exponential phase, fully ${ }^{13} \mathrm{C}$-labeled S. enterica $(50 \mathrm{~mL}$ of culture volume at $\mathrm{OD}_{650}$ 0.32) were pelleted by centrifugation and their metabolites were serially extracted into a total volume of $700 \mu \mathrm{L}$ as described earlier in the text. An aliquot of $50 \mu \mathrm{L}$ of this extract was then mixed with an equal volume of unlabeled metabolite standard mix containing $200 \mathrm{ng} / \mathrm{mL}$ of each of glutamate and glutamine, to yield a final unlabeled glutamate and glutamine concentration in the mixture of 100 $\mathrm{ng} / \mathrm{mL}$. Analysis of this sample by LC-MS/MS yielded the following peak heights: ${ }^{13} \mathrm{C}$-glutamate, $3.1 \times 10^{7}$; ${ }^{12} \mathrm{C}$-glutamate, $9.2 \times 10^{4} ;{ }^{13} \mathrm{C}$-glutamine, $7.5 \times 10^{6}$; ${ }^{12} \mathrm{C}$-glutamine, $4.5 \times 10^{5}$. The absolute ${ }^{13} \mathrm{C}$-glutamate concentration in the sample was calculated as follows:

$$
\begin{aligned}
& {\left[{ }^{13} \mathrm{C} \text {-glutamate }\right]=} \\
& 100 \mathrm{ng} / \mathrm{mL} \times \frac{{ }^{13} \mathrm{C} \text {-peak height }}{{ }^{12} \mathrm{C} \text {-standard height }}=34 \mu \mathrm{g} / \mathrm{mL}
\end{aligned}
$$

Thus, the $50-\mathrm{mL}$ culture contained a total glutamate content of $34 \mu \mathrm{g} / \mathrm{mL} \times 0.7 \mathrm{~mL}$ extraction volume $\times$ twofold dilution factor $=48 \mu \mathrm{g}$ and, analogously, a total glutamine content of $2.4 \mu \mathrm{g}$. Drying and weighing of an equivalent $50 \mathrm{~mL}$ of $S$. enterica culture (of identical $\mathrm{OD})$ yielded a cell dry weight (CDW) of $8 \mathrm{mg}$. Thus, the cellular glutamate content is $6 \mu \mathrm{g} / \mathrm{mg} \mathrm{CDW}$, which is equivalent to $40 \mathrm{nmol} / \mathrm{mg} \mathrm{CDW}$; analogously, the cellular glutamine content is $2 \mathrm{nmol} / \mathrm{mg} \mathrm{CDW}$.

\section{Results and Discussion}

\section{Assay Development and Validation for Purified Metabolites}

The current assay focuses on nitrogen-containing compounds involved in core metabolic or biosynthetic processes for which purified forms of the compounds are commercially available. It involves separation of the compounds using typical reverse-phase chromatography, followed by detection of the compounds using triple-quadrupole mass spectrometry in SRM mode. The product ions to monitor by SRM were selected based on the MS/MS fragmentation pattern of each metabolite, which was determined using the commer- 
cially available purified standard. Figure 1 shows representative LC-MS/MS chromatograms for five different compound standards, with multiple different SRM scan events superimposed on a single figure. Table 1 provides the MS/MS fragmentation results (positiveion mode) and LC retention times for all 90 studied metabolites. Each parent ion gives a number of product ions and the preferred product was selected to give the best signal-to-noise in the LC-MS/MS analysis, while also avoiding, when relevant, interference from any other compounds of the same parent mass and similar LC retention time. Notably, the chromatography portion of the current assay is imperfect, in that many compounds elute closely packed together between 5and 8-min retention time. In addition, a few compounds show peak splitting. Nevertheless, as described in the following paragraphs, the combined power of LC and MS/MS enables sensitive and specific detection of most metabolites.

Before using the assay, the stability of the 90 metabolites being studied was determined. Purified metabolites were stored for 1 week at $-80,-20$, or $4{ }^{\circ} \mathrm{C}$ in acidic ( $\mathrm{pH}$ 3.8) methanol/water solution. Of the 90 compounds in Table 1, 87 were stable during the 1-week test (final peak height $=$ initial peak height \pm $15 \%)$. The three unstable compounds were dihydrofolate, tetrahydrofolate (THF), and 5-methyltetrahydrofolate (5-methyl-THF), each of which showed a half-life of less than 1 week at $4{ }^{\circ} \mathrm{C}$ and was accordingly omitted from all additional analyses.

The LOD of the remaining 87 stable metabolites was determined by analyzing the signal-to-noise at different concentrations. The results are summarized in Table 1 and the distribution of LOD can be seen in Figure 2a. Over $85 \%$ of the compounds show an LOD of $10 \mathrm{ng} / \mathrm{mL}$ or lower, indicating the sensitivity of the present method. The linearity of the assay also was explored, in the range from each metabolite's LOD up to 100 times the LOD (stopping at a maximum concentration of 2 $\mu \mathrm{g} / \mathrm{mL}$ for those metabolites with a LOD $>20 \mathrm{ng} / \mathrm{mL}$ ). Exemplary data, corresponding to glutamine, are shown in Figure $2 \mathrm{~b}$. For all but one compound, folate, the assay yields an $R^{2}>0.95$ for linear regression of signal versus metabolite concentration, with $R^{2}>0.98$ for more than $90 \%$ of the compounds and $R^{2}>0.99$ for more than $80 \%$ of the compounds. Thus, the assay is linear over two orders of magnitude for most of the compounds.

Reproducibility of the assay for purified metabolites was evaluated by measuring the relative standard deviation (RSD) between runs, both within and between days, for a mixture containing all 87 of the studied stable metabolites, at a concentration of $500 \mathrm{ng} / \mathrm{mL}$ each, with the signal for each test compound normalized to the signal for the internal standard reserpine. Intra-day reproducibility was determined by conducting four repeat runs on each of 3 days. The mean intra-day RSD was $6 \%$ and was less than $15 \%$ for all of the compounds on at least 2 of the 3 test days, with $95 \%$
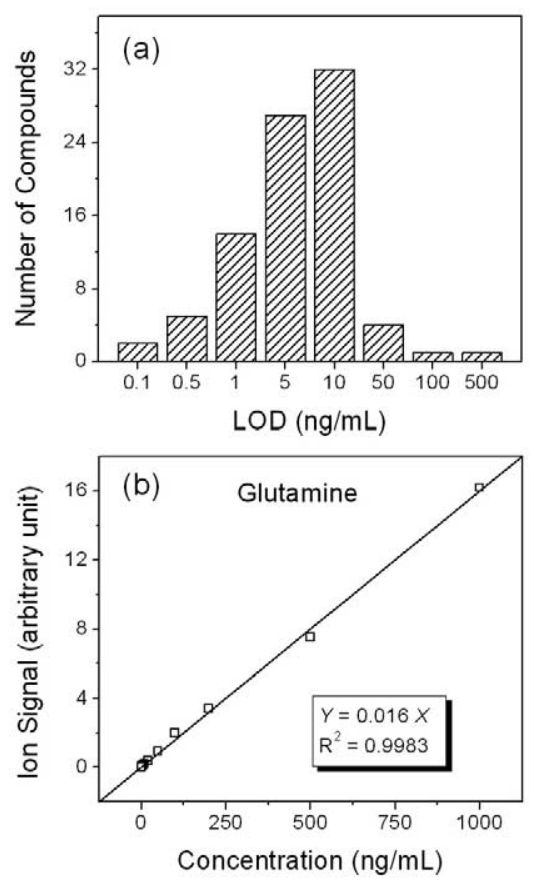

Figure 2. LC-MS/MS method performance for purified metabolites. (a) Histogram of the distribution of the LOD for the 87 stable, purified compounds listed in Table 1. (b) Representative linearity test results for glutamine.

of the compounds having an RSD $<15 \%$ on all 3 test days (exceptions: urea, xanthine, allantoin, and deoxyuridine, which all were nevertheless associated with an RSD $<25 \%$ on all test days). Regarding the inter-day reproducibility, the mean RSD across all 12 runs divided over the 3 different days was $9 \%$, with $97 \%$ of the compounds showing an RSD $<15 \%$ (exceptions, urea, xanthine, and oxidized glutathione, which all were nevertheless associated with an RSD $<25 \%$ ). Thus, for most compounds, the reproducibility of analysis using the current method is comparable with that typically achieved with SRM methods focusing on only one or a few analytes.

\section{Extraction of Metabolites from S. Enterica}

The foregoing method, having been validated with respect to its performance on purified metabolites, was used to study the extraction of metabolites from the bacterium S. enterica. Extracts were produced by centrifugation of $S$. enterica liquid culture to yield a concentrated cell pellet, followed by addition of cold $(-75$ $\left.{ }^{\circ} \mathrm{C}\right)$ methanol/water mixture to the cell pellet to quench metabolism and extract metabolites. The cold methanol/water likely releases metabolites in part through membrane disruption induced by formation of microscopic ice crystals. Three rounds of serial extraction with methanol/water, the first two at $-75^{\circ} \mathrm{C}$ and the final one at $4{ }^{\circ} \mathrm{C}$, were used to attempt to release most cellular metabolites while avoiding conditions likely to cause metabolite degradation such as heat, acid, or base [14]. 


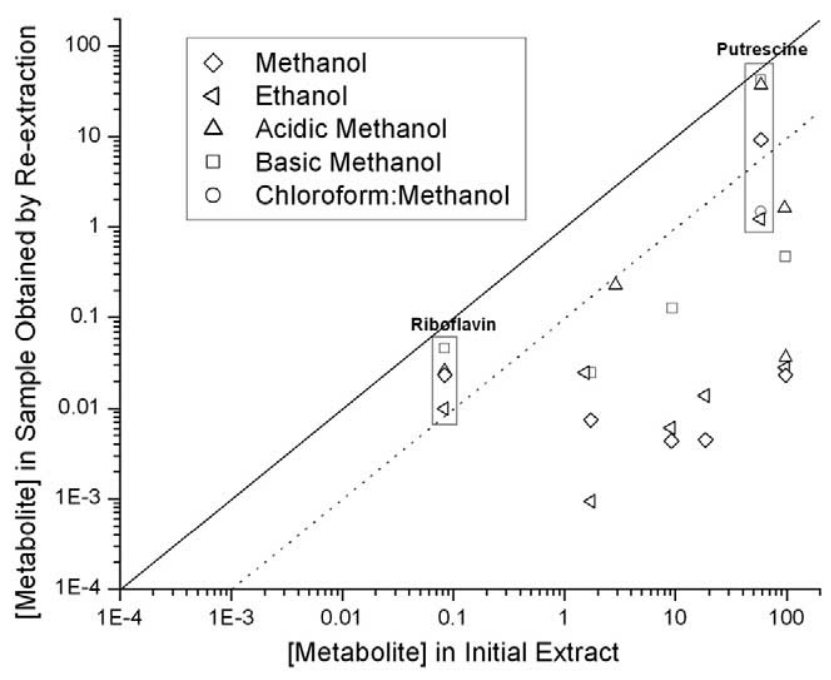

Figure 3. Efficiency of metabolite extraction. S. enterica were serially extracted three times with 80:20 methanol/water. The residual cellular material was then re-extracted with different solvents as indicated in the figure and described in greater detail in the Experimental section. Of the metabolites detected in the initial serial extracts, $70 \%$ were not detected with any method of re-extraction and are not included in the figure. For those metabolites detected with at least one method of re-extraction, the concentration of that metabolite in the initial extract ( $X$-axis) is plotted versus the concentration obtained on re-extraction $(Y-$ axis). The solid line is the line of unity. The finding that all points fall to the right of this line indicates that every metabolite was more concentrated in the initial sample than in any sample produced by re-extraction. The dashed line is the line of $10 \%$. Points falling to the right of this line indicate that the initial sample contained at least tenfold more concentrated metabolite than the sample produced by re-extraction.

The effectiveness of the foregoing serial extraction procedure in releasing metabolites was explored by re-extracting the residual cellular material remaining after the three rounds of serial extraction. For reextraction, a variety of different solvent systems were tested: methanol, ethanol, acidic methanol, basic methanol, and chloroform/methanol. Of the compounds found in detectable amounts in the initial serial extracts, $70 \%$ were not detectable after re-extraction with any of the tested solvents. The concentrations of the compounds that were detectable after re-extraction are shown in Figure 3, plotted versus the concentration of the same compound found in the initial extract. For all re-extraction solvents, all compounds were found in lower concentrations on re-extraction than initial extraction, with only riboflavin and putrescine found on re-extraction at concentrations of more than $10 \%$ of those present in the initial extract. Thus, our threeround serial extraction procedure seems to release most metabolites effectively.

\section{Assay Development and Validation for Quantitative Comparison of Biological Extracts}

For quantitative analysis of biological extracts, we aimed to develop a method involving measurement of the ratios of unlabeled versus isotope-labeled metabolites, because this approach has the potential to control for ion suppression and other effects that could otherwise cause spurious findings in a mixture as complex as a cellular extract. To generate isotope-labeled forms of metabolites, S. enterica was grown in uniformly ${ }^{13} \mathrm{C}$ labeled glucose (in the absence of any other carbon sources), which by necessity must result, after numerous rounds of cell divisions, in uniform ${ }^{13} \mathrm{C}$-labeling of all intracellular metabolites.

To determine which metabolites could potentially be measured reliably from $S$. enterica extracts using this approach, we searched for metabolites that met the following criteria: (1) the peak corresponding to the ${ }^{12} \mathrm{C}$-metabolite (the ${ }^{12} \mathrm{C}$-peak) is much larger for cells grown in unlabeled (essentially ${ }^{12} \mathrm{C}$-) glucose than for cells grown in ${ }^{13} \mathrm{C}$-glucose, (2) the ${ }^{13} \mathrm{C}$-peak is much larger for cells grown in ${ }^{13} \mathrm{C}$-glucose than for cells grown in unlabeled glucose and is comparable in magnitude with the ${ }^{12} \mathrm{C}$-peak for cells grown in unlabeled glucose, and (3) the ${ }^{13} \mathrm{C}$-peak overlays perfectly with the ${ }^{12} \mathrm{C}$-peak when extract from cells grown in ${ }^{13} \mathrm{C}$-glucose are spiked with purified unlabeled metabolite. In Figures 4 and 5, we show representative results using the amino acid glutamate as an example. In total, 36 metabolites met the foregoing criteria and are listed in Table 2. The ${ }^{12} \mathrm{C}$-signal in Table 2 refers to the ${ }^{12} \mathrm{C}$-peak observed for cells grown in unlabeled glucose, and the ${ }^{12} \mathrm{C}$-noise (expressed as a percent of the ${ }^{12} \mathrm{C}$-signal) refers to the ${ }^{12} \mathrm{C}$-peak for cells grown in ${ }^{13} \mathrm{C}$-glucose. The ${ }^{13} \mathrm{C}$-signal and noise are defined analogously.

Based on the foregoing results, we developed an LC-MS/MS method, which involves 72 SRMs, corresponding to the uniformly ${ }^{12} \mathrm{C}$ - and ${ }^{13} \mathrm{C}$-forms of each of the 36 metabolites listed in Table 2. To determine the metabolite profile of a test culture, we grow the test culture using unlabeled media of our choosing and mix the resulting extract with ${ }^{13} \mathrm{C}$-extract produced from cells grown under fixed conditions, with the ${ }^{13} \mathrm{C}$-metabolites serving as internal standards for the ${ }^{12} \mathrm{C}$-metabolites from the test culture. The concentration of test metabolite is then reported as the ratio of the ${ }^{12} \mathrm{C}$-signal to the ${ }^{13} \mathrm{C}$-signal in the extract mix. Theoretically, in this manner, we can compare any number of cultures grown under different conditions by mixing an extract from each of these unlabeled cultures with a fixed internal standard ${ }^{13} \mathrm{C}$-extract.

To determine the reproducibility of LC-MS/MS measurement using this ${ }^{12} \mathrm{C} /{ }^{13} \mathrm{C}$-metabolite ratio approach, we analyzed two different extract mixtures repeatedly ( $n=3$ runs for each of two extract mixtures). The mean RSD for repeated measurement of the same sample was $12 \%$ and was strongly influenced by a few metabolites associated with larger RSDs, with the median RSD only $7 \%$. The largest RSDs were associated with O-acetyl-Lserine $(37 \%)$ and glucosamine-6-phosphate $(40 \%)$, both compounds with relatively poor signal-to-noise in $S$. enterica extracts (Table 2). Overall, the reproducibility of analysis of the mixed extract samples generally was in 

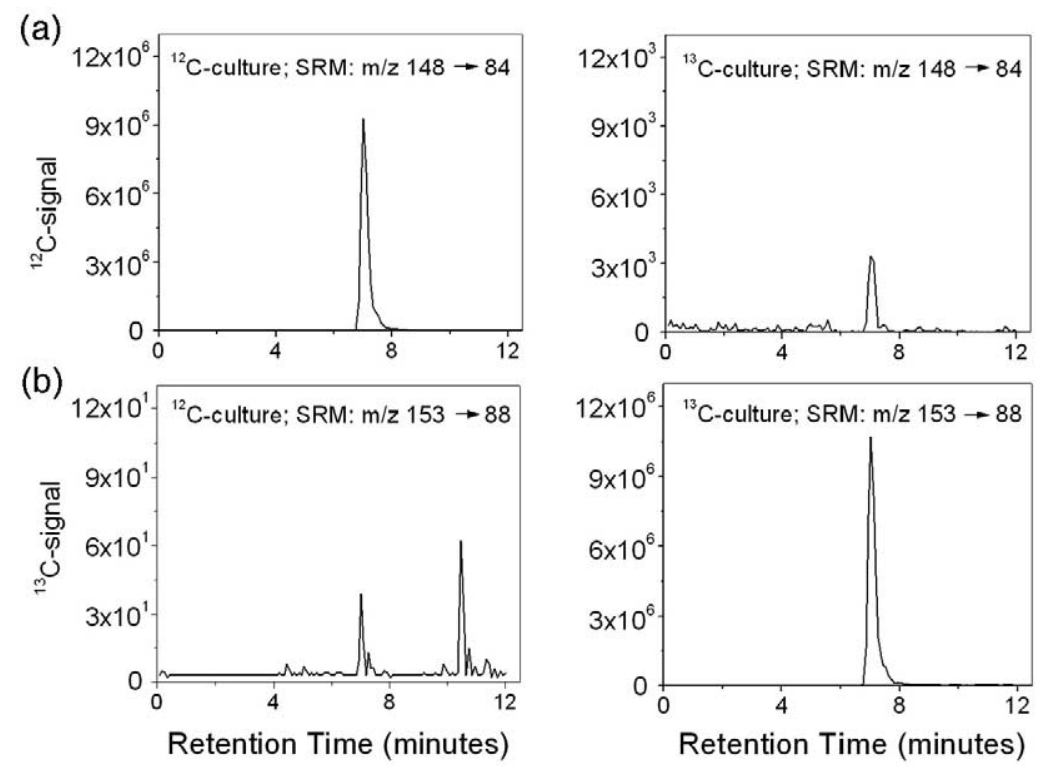

Figure 4. Measurement of ${ }^{12} \mathrm{C}$ - versus ${ }^{13} \mathrm{C}$-glutamate in extracts of bacteria grown in unlabeled versus ${ }^{13} \mathrm{C}$-labeled glucose. Chromatograms show the ${ }^{12} \mathrm{C}$-glutamate SRM signal (a) and ${ }^{13} \mathrm{C}$ glutamate SRM signal (b) for extract from S. enterica grown in unlabeled glucose (left) or ${ }^{13} \mathrm{C}$-glucose (right). Note that the absolute magnitude of the signal (maximum $Y$-axis value) in the top left and bottom right panels greatly exceeds that in the other panels.

the range typical for quantitative, isotope-ratio-based LC-MS/MS methods.

Having determined that ratio-based analysis of any particular sample is reasonably reproducible, we explored the reproducibility of our overall process, starting with cell culture and proceeding through to LCMS/MS analysis, using mixed extracts produced from four different sets of exponential-phase ${ }^{12} \mathrm{C}$ - and ${ }^{13} \mathrm{C}$ -
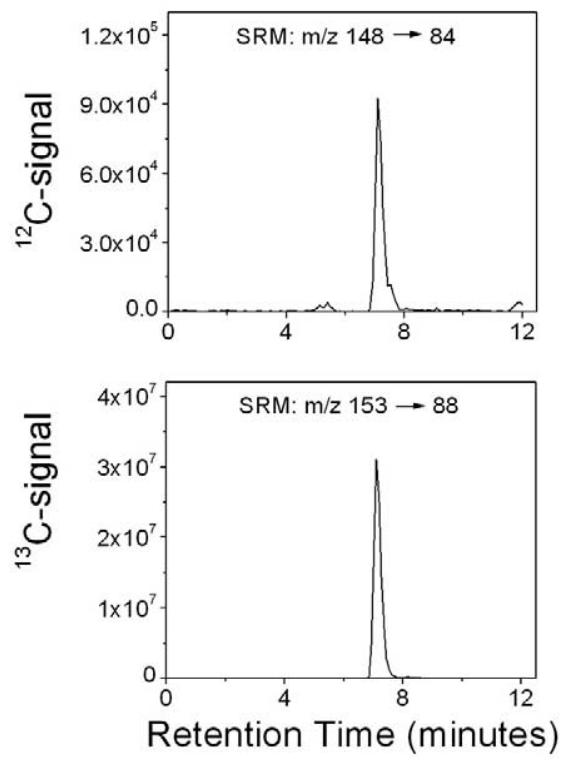

Figure 5. Spiking of ${ }^{13} \mathrm{C}$-labeled S. enterica extract with unlabeled purified glutamate $(100 \mathrm{ng} / \mathrm{mL})$. The top chromatogram shows the ${ }^{12} \mathrm{C}$-glutamate SRM signal and the bottom shows the ${ }^{13} \mathrm{C}$ glutamate SRM signal. cultures grown on 4 different days. The variability associated with cell culture and extraction was substantial, resulting in a mean RSD between theoretically identical mixed extracts of 39\%. These results highlight the challenges in growing and extracting bacteria in a manner that produces a consistent metabolome extract. Work to address these challenges is ongoing.

\section{Metabolome Differences between Growing and Carbon-Starved S. enterica}

Despite the observed culture-to-culture variability with fixed cell growth conditions, we were curious whether changes in the $S$. enterica metabolome associated with biological manipulations could be detected by our ratiobased method. Therefore, we compared exponentially growing $S$. enterica with $S$. enterica driven into stationary phase by carbon starvation, using the same ${ }^{13} \mathrm{C}$ extract as the internal control for both test conditions. To mitigate the effects of culture-to-culture variability, four independent sets of exponential- and stationaryphase cultures were compared. Following the tradition of analysis of genome-wide expression analysis using DNA microarrays, we report our results as the log (concentration in the stationary-phase cells/concentration in the exponential-phase cells; Figure 6). The statistical significance of the observed metabolite concentration changes can be assessed using $t$-test to compare the log values from the two different culture conditions, with 21 of the 36 metabolites investigated showing a statistically significant change in concentration between exponential and stationary phase as indicated by $\mathrm{p}<$ 


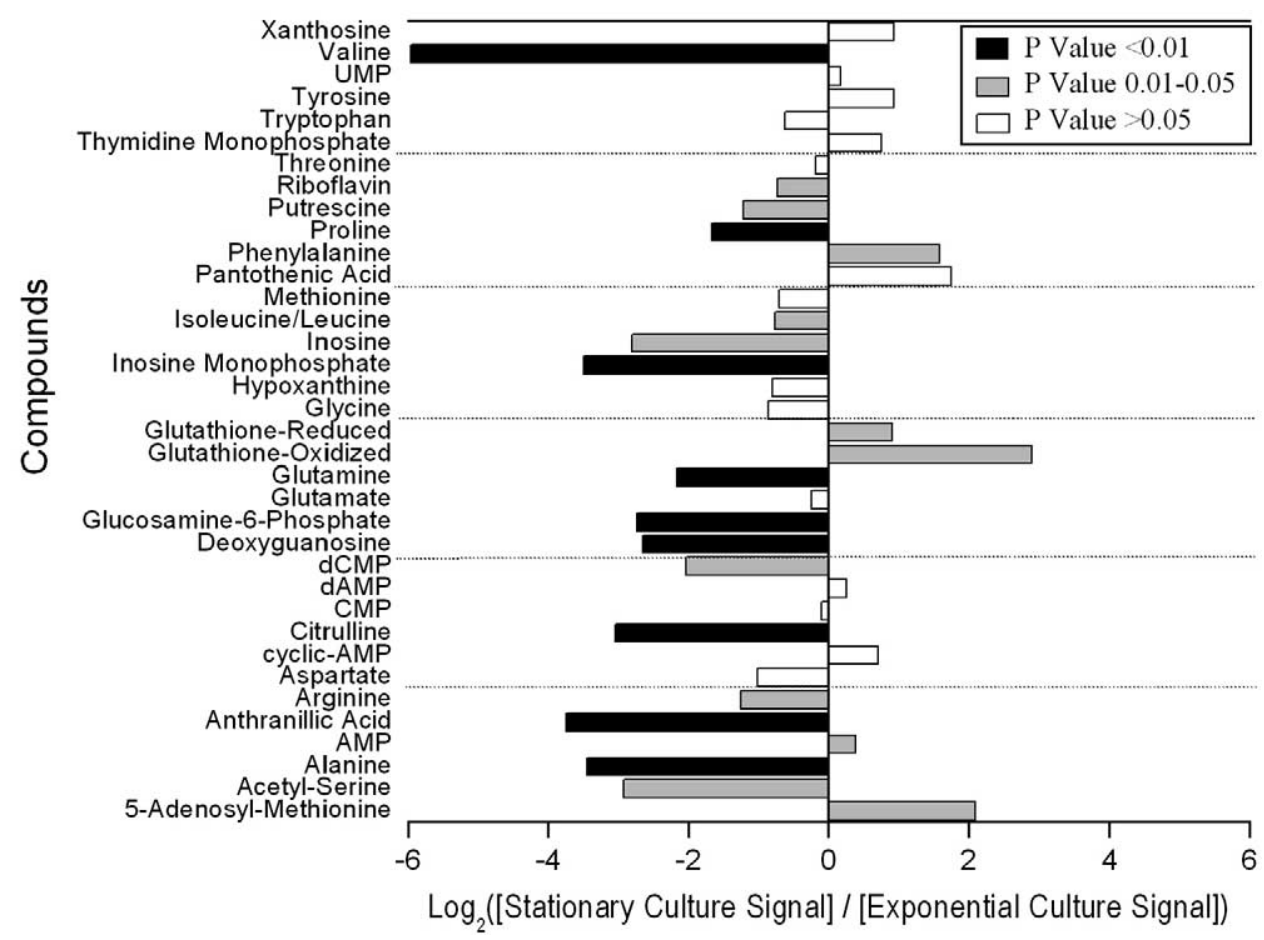

Figure 6. Metabolome differences between growing (exponential culture) and carbon-starved (stationary culture) S. enterica. Data represent the average of four independent stationary-phase and exponential-phase cultures.

0.05. Because we are making 36 statistical comparisons, some of the results at $\mathrm{p}<0.05$ are likely because of chance alone; nevertheless, the expected number of false discoveries is less than 2 of the 21 discoveries made. Thus, despite the culture-to-culture variability we observe, we are able to identify numerous changes in metabolome composition associated with bacterial entry into the stationary phase.

The metabolite profile observed in the stationaryphase cells is notable in several respects. Many more metabolites are decreased than increased in concentration in the stationary phase, as might be expected for less metabolically active cells. A few metabolites, however, are increased in the stationary phase, including glutathione (both oxidized and reduced), which may provide protection for the stationary cells against redox stress [38]. In terms of metabolites that decreased in concentration, the most striking result is for the amino acid valine, which decreased approximately 60-fold, with alanine also markedly decreased. To our knowledge, large decreases in the concentrations of these amino acids in bacterial stationary phase have not been reported previously. Alanine and valine are both products of pyruvate; accordingly, it will be interesting in future studies to determine the concentration of pyruvate in stationary-phase cells. Other metabolites showing marked decreases during stationary phase include various metabolic intermediates and glutamine. Additional experiments involving stationary phase induced by various different stimuli (e.g., other types of nutrient starvation) and including holistic analysis of cellular transcriptional events will be required to attach greater biological meaning to these preliminary findings.

\section{Methodology for Absolute Quantitation of Cellular Metabolite Content}

An isotope-ratio-based approach also can be used for absolute quantitation of cellular metabolite content using data of the type shown in Figure 5 [23]. The absolute concentration of ${ }^{13} \mathrm{C}$-cellular metabolite in a test sample is determined based on the relative size of the ${ }^{13} \mathrm{C}$-peak corresponding to the extracted cellular metabolite versus the ${ }^{12} \mathrm{C}$-peak corresponding to a known concentration of purified standard. Because the present LCMS/MS method is linear, the absolute ${ }^{13} \mathrm{C}$-metabolite concentration, $\left[{ }^{13} \mathrm{C}\right.$-cellular metabolite], can be calculated as follows:

$$
\begin{aligned}
& {\left[{ }^{13} \mathrm{C} \text {-cellular metabolite }\right]=} \\
& {\left[{ }^{12} \mathrm{C} \text {-standard }\right] \times \frac{{ }^{13} \mathrm{C} \text {-peak height }}{{ }^{12} \mathrm{C} \text {-standard height }}}
\end{aligned}
$$

The absolute ${ }^{13} \mathrm{C}$-metabolite concentration multiplied by the extract volume and the dilution factor introduced when adding the ${ }^{12} \mathrm{C}$-standard determines the absolute metabolite yield from the collected cells. Dividing by the dry weight of the collected cells then yields the metabolite yield per CDW. In this manner, we have determined that our $S$. enteric extracts contain 
$40 \mathrm{nmol}$ of glutamate and $2 \mathrm{nmol}$ of glutamine per milligram of CDW. We focus on absolute quantitation of these two metabolites because their absolute concentrations in S. enterica have previously been determined carefully by alternative means [12]. Our results are consistent with the prior literature, falling in the middle of the range of the glutamine and glutamate quantities previously reported in various strains of $S$. enterica under different growth conditions [12].

\section{Conclusion}

LC-MS/MS with ESI is well recognized as a powerful means of characterizing chemical mixtures. Here, we show that triple-quadrupole LC-MS/MS can be used to quantitate numerous known metabolites in parallel, by scanning repeatedly through different SRM events. Such an LC-MS/MS approach works effectively for 90 purified metabolites and in theory still could be expanded to a greater number without compromising quantitative performance.

When applying LC-MS/MS to quantify components of a complicated sample, use of isotope-labeled internal standard corrects for many potential sources of artifact, most importantly those arising from ion suppression caused by coeluting compounds. Consistent with previous reports that involved a smaller number of metabolites [20-23], here, we find that isotope-labeled standard for cellular metabolites can be produced by extracting cells grown in uniformly ${ }^{13} \mathrm{C}$-labeled glucose. The absolute concentration of metabolites in this ${ }^{13} \mathrm{C}$ extract can be determined by spiking the extract with known concentrations of purified unlabeled metabolite standards [23]. Mixing this ${ }^{13} \mathrm{C}$-internal standard extract into unlabeled test extract enables isotope-ratio-based metabolite quantitation, with the method described here involving 72 SRM scans to measure the ${ }^{12} \mathrm{C}$ - and ${ }^{13} \mathrm{C}$-forms of each of 36 metabolites. This 72-SRM method provides a useful tool for exploring the effect of cell growth conditions on intracellular metabolite concentrations. For example, we find statistically significant changes in the concentrations of 21 metabolites associated with bacterial entry into the stationary phase. Many of the metabolite concentration changes reflect new biological discoveries that may facilitate efforts toward a complete understanding of cellular physiology.

\section{Acknowledgments}

The authors thank David Botstein for motivating this line of research and the Lewis-Sigler Institute and Department of Chemistry at Princeton University for funding these efforts. The also thank Jie Yuan, Robert Moder, Sunil Bajad, Melisa Gao, Sanford Silverman, Celeste Peterson, Thomas Silhavy, and John T. Groves for their valuable comments, suggestions, and technical assistance.

\section{References}

1. Keseler, I. M.; Collado-Vides, J.; Gama-Castro, S.; Ingraham, J.; Paley S.; Paulsen, I. T.; Peralta-Gil, M.; Karp, P. D. EcoCyc: A Comprehensive Database Resource for Escherichia coli. Nucleic Acids. Res. 2005, 33, D334-D337.

2. Edwards, J. S.; Palsson, B.Ø. The Escherichia coli MG1655 in silico Metabolic Genotype: Its Definition, Characteristics, and Capabilities. Proc. Natl. Acad. Sci. U.S.A. 2000, 97, 5528-5533.

3. Ouzonis, C.; Karp, P. D. Global Properties of the Metabolic Map of Escherichia coli. Genome Res. 2000, 10, 568-576.

4. Reed, J. L.; Vo, T. D.; Schilling, C. H.; Palsson, B.Ø. An Expanded Genome-Scale Model of Escherichia coli K-12 (iJR904 GSM/GPR). Genome Biol. 2003, 4, R54.1-R54.12.

5. Fong, S. S.; Palsson, B.Ø. Metabolic-Deletion Strains of Escherichia coli Evolve to Computationally Predicted Growth Phenotypes. Nat. Genet. 2004, 36, 1056-1058.

6. Förster, J.; Famili, I.; Fu, P. C.; Palsson, B. Ø.; Nielsen, J. Genome-Scale Reconstruction of the Saccharomyces cerevisiae Metabolic Network. Genome. Res. 2003, 13, 244-253.

7. Duarte, N. C.; Herrgard, M. J.; Palsson, B. Ø. Reconstruction and Validation of Saccharomyces cerevisiae iND750, a Fully Compartmentalized Genome-Scale Metabolic Model. Genome Res. 2004, 14, 1298-1309.

8. Ruijter, G. J. G.; Visser, J. Determination of Intermediary Metabolites in Aspergillus niger. J. Microbiol. Methods 1996, 25, 295-302.

9. Theobald, U.; Mailinger, W.; Baltes, M.; Rizzi, M.; Reuss, M. In Vivo Analysis of Metabolic Dynamics in Saccharomyces cerevisiae: I. Experimental Observations. Biotechnol. Bioeng. 1997, 55, 305-316.

10. Hajjaj, H.; Blanc, P. J.; Goma, G.; Francois, J. Sampling Techniques and Comparative Extraction Procedures for Quantitative Determination of Intra- and Extracellular Metabolites in Filamentous Fungi. FEMS Microbiol. Lett. 1998, 164, 195-200.

11. Neidhardt, F. C.; Ingraham, J. L.; Schaechter, M. Physiology of the Bacterial Cell: A Molecular Approach; Sinauer Associates, Inc.: Sunderland, MA, 1990.

12. Ikeda, T. P; Shauger, A. E.; Kustu, S. Salmonella typhimurium Apparently Perceives External Nitrogen Limitation as Internal Glutamine Limitation, J. Mol. Biol. 1996, 259, 589-607.

13. Tweeddale H.; Notley-Mcrobb, L.; Ferenci, T. Effect of Slow Growth on Metabolism of Escherichia coli, as Revealed by Global Metabolite Pool ("Metabolome") Analysis. J. Bacteriol. 1998, 180, 5109-5116.

14. Maharjan, R. P.; Ferenci, T. Global Metabolite Analysis: The Influence of Extraction Methodology on Metabolome Profiles of Escherichia coli. Anal. Biochem. 2003, 313, 145-154.

15. Wittmann C.; Krömer J. O.; Kiefer, P.; Binz, T.; Heinzle, E. Impact of the Cold Shock Phenomenon on Quantification of Intracellular Metabolites in Bacteria. Anal. Biochem. 2004, 327, 135-139.

16. Tang, H.; Wang, Y.; Nicholson, J. K.; Lindon, J. C. Use of RelaxationEdited One-Dimensional and Two-Dimensional Nuclear Magnetic Resonance Spectroscopy to Improve Detection of Small Metabolites in Blood Plasma. Anal. Biochem. 2004, 325, 260-272.

17. Pelczer, I. High-Resolution NMR for Metabomics. Curr. Opin. Drug Discov. Devel. 2005, 8, 127-133.

18. Wang, W. X.; Zhou, H. H.; Lin, H.; Roy, S.; Shaler, T. A.; Hill, L. R.; Norton, S.; Kumar, P.; Anderie, M.; Becker, C. H. Quantification of Proteins and Metabolites by Mass Spectrometry Without Isotope Labeling or Spiked Standards. Anal. Chem. 2003, 75, 4818-4826.

19. Roy, S. M.; Anderle, M.; Lin, H.; Becker, C. H. Differential Expressing Profiling of Serum Proteins and Metabolites for Biomarker Discovery. Int. J. Mass. Spectrom. 2004, 238, 163-171.

20. Van Dam, J. C.; Eman, M. R.; Frank, J.; Lange, H. C.; van Dedem, G. W. K.; Heijnen, S. J. Analysis of Glycolytic Intermediates in Saccharomyces cerevisiae Using Ion-Exchange Chromatography and Electrospray Ionization With Tandem Mass Spectrometry Detection. Anal. Chim. Acta. 2002, 460, 209-218.

21. Mashego, M. R.; Wu, L.; Van Dam, J. C.; Ras, C.; Vinke, J. L.; Van Winden, W. A.; Van Gulik, W. M.; Heijnen, J. J. MIRACLE. Mass Isotopomer Ration Analysis of U- ${ }^{13} \mathrm{C}$-Labeled Extracts. A New Method for Accurate Quantification of Changes in Concentrations of Intracellular Metabolites. Biotechnol. Bioeng. 2004, 85, 620-628.

22. Mashego, M. R.; Jansen, M. L. A.; Vinke, J. L.; van Gulik, W. M.; Heijnen, J. J. Change in the Metabolome of Saccharomyces cerevisiae Associated With Evolution in Aerobic Glucose-Limited Chemostats. FEMS Yeast Res. 2005, 5, 419-430.

23. Wu, L.; Mashego, M. R.; van Dam, J. C.; Proell, A. M.; Vinke, J. L.; Ras, C.; van Winden, W. A.; van Gulik, W. M.; Heijnen, J. J. Quantitative Analysis of the Microbial Metabolome by Isotope Dilution Mass Spectrometry Using Uniformly ${ }^{13} \mathrm{C}$-Labeled Cell Extracts as Internal Standards. Anal. Biochem. 2005, 336, 164-171.

24. Chovan L. E.; Black-Schaefer C.; Dandliker, P. J.; Lau, Y. Y. Automatic Mass Spectrometry Method Development for Drug Discovery: Application in Metabolic Stability Assays. Rapid Commun. Mass. Spectrom. 2004, 18, 3105-3112.

25. Hong, Y. J.; Mitchell, A. E. Metabolic Profiling of Flavonol Metabolites in Human Urine by Liquid Chromatography and Tandem Mass Spectrometry. J. Agric. Food. Chem. 2004, 52, 6794-6801.

26. Olsson A. O.; Baker S. E.; Nguyen J. V.; Romanoff L. C.; Udunka S. O.; Walker R. D.; Flemmen K. L.; Barr, D. B. A Liquid ChromatographyTandem Mass Spectrometry Multiresidue Method for Quantification of 
Specific Metabolites of Organophosphorus Pesticides, Synthetic Pyrethroids, Selected Herbicides, and DEET in Human Urine. Anal. Chem. 2004, 76, 2453-2461.

27. Dookeran N. N.; Yalcin T.; Harrison, A. G. Fragmentation Reactions of Protonated $\alpha$-Amino Acids. J. Mass. Spectrom. 1998, 31, 500-508.

28. Rogalewicz, F.; Hoppilliard, Y.; Ohanessian, G. Fragmentation Mechanism of $\alpha$-Amino Acids Protonated under Electrospray Ionization: A Collision Activation and ab initio Theoretical Study. Int. J. Mass Spectrom. 2000, 195/196, 565-590.

29. Piraud M.; Vianey-Saban C.; Petritis K.; Elfakir C.; Steghens J.P.; Morla A.; Bouchu D. ESI-MS/MS Analysis of Underivatised Amino Acids: A New Tool for the Diagnosis of Inherited Disorders of Amino Acid Metabolism. Fragmentation Study of 79 Molecules of Biological Interest in Positive and Negative Ionization Mode. Rapid Commun. Mass Spectrom. 2003, 17, 12971311.

30. Aribi A. H.; Orlova G.; Hopkinson A. C.; Siu, K. W. M. Gas-Phase Fragmentation Reactions of Protonated Aromatic Amino Acids: Concomitant and Consecutive Neutral Eliminations and Radical Cation Formations. J. Phys. Chem. A 2004, 108, 3844-3853.

31. Csonka I. P.; Paizs B.; Suhai, S. Modeling of the Gas-Phase Ion Chemistry of Protonated Arginine. J. Mass Spectrom. 2004, 39, 1025-1035.

32. Harrison, A. G. Fragmentation Reaction of Protonated Peptides Containing Glutamine or Glutamic Acid. J. Mass Spectrom. 2003, 38, 174-187.
33. Moore, I. F.; Kluger, R. Substituent Effects in Carbon-Nitrogen Cleavage of Thiamin Derivatives. Fragmentation Pathways and Enzymic Avoidance of Cofactor Destruction. J. Am. Chem. Soc. 2002, 124, 1669-1673.

34. Bandu M. L.; Watkins K. R.; Brettahauer M. L.; Moore C. A.; Besaire, H. Prediction of MS/MS Data: 1. A Focus on Pharmaceuticals Containing Carboxylic Acids. Anal. Chem. 2004, 76, 1746-1753.

35. Jovanović B. Z.; Perić-Grujić A. A.; Marinković A. D.; Vajs, V. V. Mass Spectrometric Study of Some 4-Pyrimidine Carboxylic Acids. Rapid Commun. Mass Spectrom. 2002, 16, 2044-2047.

36. Nelson C. C.; McCloskey, J. A. Collision-Induced Dissociation of Uracil and Its Derivatives. J. Am. Soc. Mass Spectrom. 1994, 5, 339-349.

37. Kerwin, J. L.; Whitney, D. L.; Sheikh, A. Mass Spectrometric Profiling of Glucosamine, Glucosamine Polymers and Their Catecholamine Adducts. Model Reactions and cuticular hydrolysates of Texorhynchites amboinensis (Culicidae) Pupae. Insect Biochem. Mol. Biol. 1999, 29, 599607.

38. Buchmeier, N.; Bossie, S.; Chen, C. Y.; Fang, F. C.; Guiney, D. G.; Libby, S. J. SlyA, A Transcriptional Regulator of Salmonella typhimurium, Is Required for Resistance to Oxidative Stress and Is Expressed in the Intracellular Environment of Macrophages. Infect. Immun. 1997, 65, $3725-2730$. 